\title{
Helical peptides design for molecular dipoles functionalization of wide band gap oxides.
}

Yuan Chen ${ }^{1}$, Jonathan Viereck ${ }^{2}$, Ryan H armer $^{1}$, Sylvie Rangan ${ }^{2}$, Robert A. Bartynski2* and Elena Galoppini*

Chemistry Department, Rutgers University, 73 Warren Street, Newark NJ 07102, USA; Department of Physics and Astronomy and Laboratory for Surface Modification, Rutgers University, 136 Frelinghuysen Road, Piscataway NJ 08854, USA.

Table of contents

1. Synthesis:

p. S-1

1a. General

1b. Synthesis of Z-(Aib) ${ }_{6}-\mathrm{COOtBu}$

1c. Synthesis of di-tert-butyl 5-(azidomethyl)isophthalate

2. Binding groups Reactivity:

p. S-9

2a. XPS/UPS

2b. FTIR

3. ${ }^{1} \mathrm{H}$ NMR characterization of peptides:

NOESY of Z-(Aib) ${ }_{6}-\mathrm{COOtBu}$

Solvent titration experiment

$\mathrm{HMBC}$ of $\mathrm{Z}-(\mathrm{Aib})_{6}-\mathrm{COOtBu}$

4. References:

p. S-15

5. Appendix:

${ }^{1} \mathrm{H},{ }^{13} \mathrm{C}$ NMR, IR and ESI Spectra

6. Crystal data and structure refinement for $\mathrm{Z}-(\mathrm{Aib})_{6}-\mathrm{COOtBu}$ 


\section{Synthesis.}

\section{1a. General.}

All the following solvents and reagents were used as received from commercial sources: $N$ benzyloxycarbonyl-2-aminoisobutyric acid (Z-Aib-OH, 97\%), 1-(3-dimethyl-aminopropyl)-3ethylcarbodiimide hydrochloride (EDC.HCl), 1-hydroxy-7-azabenzotriazole (HOAT, 98\%), 4methylmorpholine (NMM, $\geq 99.5 \%$ ), 2-aminoisobutyric acid tert-butyl ester (H-Aib-COOtBu, 98\%), trifluoroacetic acid (TFA, 99\%), 10\% Palladium on activated charcoal (10\% $\mathrm{Pd} / \mathrm{C})$, acetonitrile (anhydrous, 99.8\%), N,N-dimethylformamide (anhydrous, 99.8\%), dichloromethane (anhydrous, $\geq 99.8 \%$ ), methanol (anhydrous), ethyl acetate (anhydrous, 99.8\%), diethyl ether (anhydrous, $\geq 99.0 \%$ ). Hexane for column chromatography was glass distilled. Tetrahydrofuran (THF) was freshly distilled under nitrogen from sodium benzophenone ketyl. The reactions were performed under nitrogen in flame or oven-dried glassware. ${ }^{1} \mathrm{H}$ and ${ }^{13} \mathrm{C}$ nuclear magnetic resonance (NMR) spectra were collected on a Varian NMR spectrometer operating at $599.714 \mathrm{~Hz}$ for ${ }^{1} \mathrm{H}$ and $150.812 \mathrm{~Hz}$ for ${ }^{13} \mathrm{C}$. Chemical shifts $(\delta)$ are reported relative to the central line of the solvent ${ }^{1}: \mathrm{CDCl}_{3}\left(\delta 7.26 \mathrm{ppm}\right.$ or TMS for ${ }^{1} \mathrm{H}$ and $\delta 77.16 \mathrm{ppm}$ for $\left.{ }^{13} \mathrm{C}\right), \mathrm{CD}_{3} \mathrm{OD}(\delta 3.31,4.85 \mathrm{ppm}$ for ${ }^{1} \mathrm{H}$ and $\delta 49.00 \mathrm{ppm}$ for $\left.{ }^{13} \mathrm{C}\right)$, DMSO-d 6 ( $\delta 2.5 \mathrm{ppm}$ for ${ }^{1} \mathrm{H}$ and $\delta 39.51 \mathrm{ppm}$ for $\left.{ }^{13} \mathrm{C}\right)$. Spin-spin coupling constants $(J)$ are reported in Hz. NMR spectra were processed using Mnova NMR from Mestrelab. ESI spectra were collected on an Apex-ultra 70 hybrid Fourier transform mass spectrometer (Bruker Daltonics). The Fourier transform infrared (FTIR) spectra were collected on a Thermo Electron Corporation Nicolet 6700 FT-IR with 128 scans and spectral resolution of 8 $\mathrm{cm}^{-1}$; cells with $\mathrm{CaF}_{2}$ windows were used (pathway length $0.0164 \mathrm{~mm}$ ).

Stability: The peptides were stored at low temperature $\left(-20^{\circ} \mathrm{C}\right)$ and in small aliquots to minimize degradation during thawing-freezing of samples. At room temperature were stable at the most two months as diluted solutions in organic solvent, but degraded rapidly when heated in the solid state. In any case the samples should be stored cold and under nitrogen and the integrity checked prior to use. 


\section{1b. Synthesis of $\mathrm{Z}$-(Aib) ${ }_{6}-\mathrm{COOtBu}^{2}$.}

l)

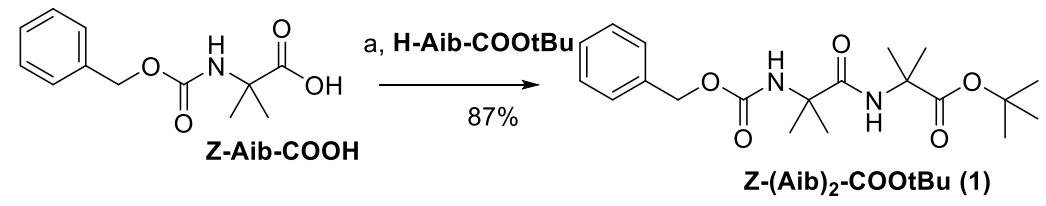

1. b
$\underset{89 \%}{2 .} a$, Z-Aib-OH

II)
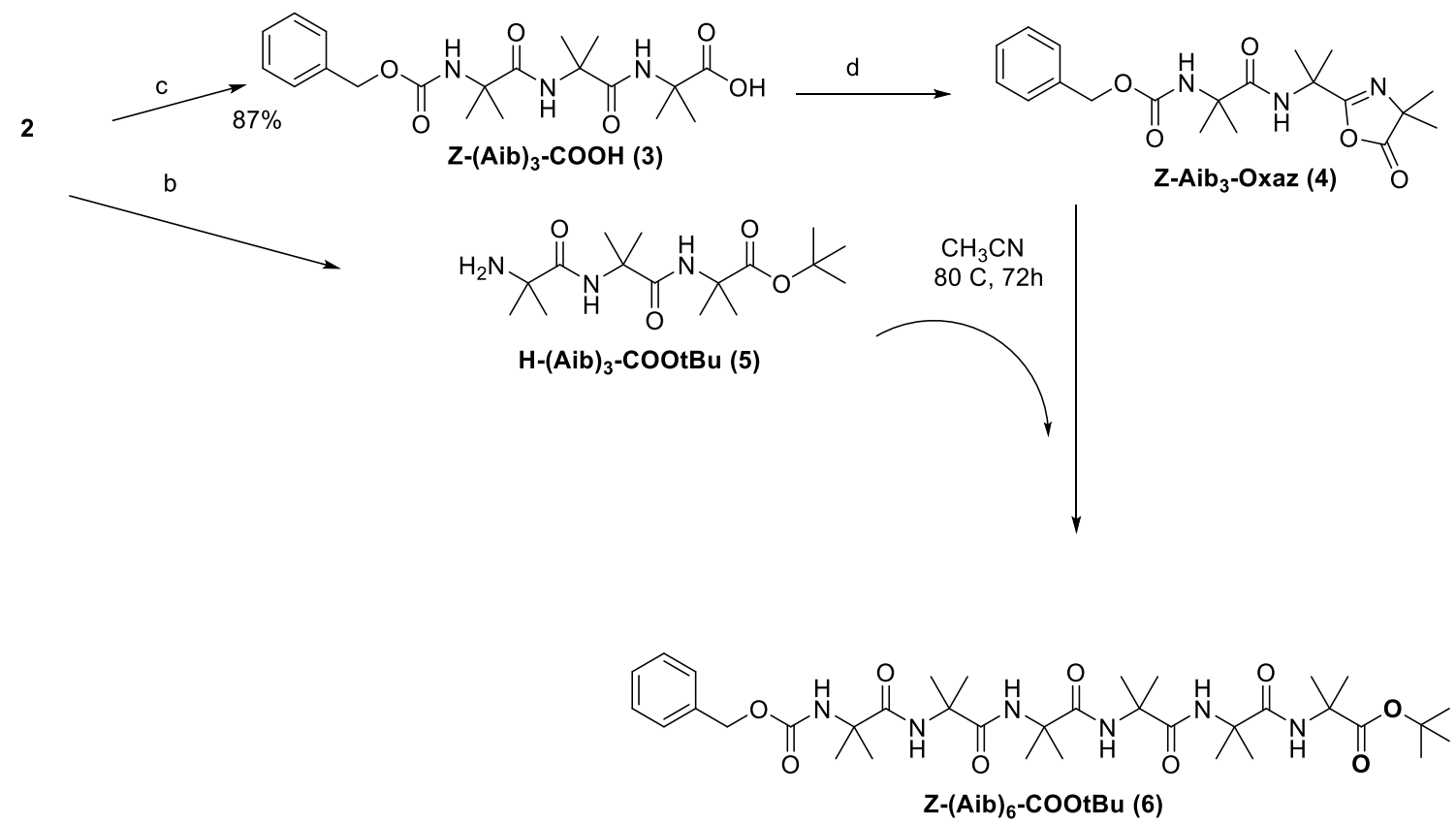

Scheme S1. Reagents and conditions: a: $\mathrm{EDC} \cdot \mathrm{HCl}, \mathrm{HOAT}, \mathrm{CH}_{2} \mathrm{Cl}_{2}$, NMM, r.t; b: $\mathrm{H}_{2}, \mathrm{Pd} / \mathrm{C}$, $\mathrm{MeOH}$; c: $\mathrm{CH}_{2} \mathrm{Cl}_{2}, \mathrm{TFA}$; d: $\mathrm{CH}_{3} \mathrm{CN}, \mathrm{EDC} \cdot \mathrm{HCl}$, r.t

Synthesis of Z-(Aib)2-COOtBu (1) ${ }^{2}$ : To a stirred solution of Z-Aib-COOH(4.5 g,19 mmol) in anhydrous $\mathrm{CH}_{2} \mathrm{Cl}_{2} \quad(38 \mathrm{ml})$ was added $\mathrm{EDC} \cdot \mathrm{HCl}$ (1-(3-dimethyl-aminopropyl)-3ethylcarbodiimide hydrochloride, $3.65 \mathrm{~g}, 19 \mathrm{mmol}$ ), HOAT (1-hydroxy-7-azabenzotriazole, $2.6 \mathrm{~g}$, $19 \mathrm{mmol}$ ), NMM (4-methylmorpholine, $2.9 \mathrm{ml}, 19 \mathrm{mmol}$ ), and allowed to stir for $20 \mathrm{~min}$ to activate the acid. Then, H-Aib-COOtBu $(3.0 \mathrm{~g}, 19 \mathrm{mmol})$ was added and allowed to stir for $16 \mathrm{~h}$ at room temperature under $\mathrm{N}_{2}$. The reaction was diluted with ethyl acetate $(100 \mathrm{ml})$ and washed with sat. $\mathrm{NH}_{4} \mathrm{Cl}(2 \times 80 \mathrm{ml})$, sat. $\mathrm{NaHCO}_{3}(2 \times 80 \mathrm{ml})$, DI water $(80 \mathrm{ml})$, brine $(80 \mathrm{ml})$, dried $\left(\mathrm{Na}_{2} \mathrm{SO}_{4}\right)$ and concentrated, purified by column chromatography (20\%-50\% EtOAc/Hexanes) to give $\mathbf{1}$ as a white 
solid (6.4 g, 87\%). ${ }^{1} \mathrm{H}$ NMR $\left(\mathrm{CDCl}_{3}\right) \delta 7.35-7.31$ (m, 5H), 6.91 (brs, 1H), 5.40 (brs, 1H), 5.09 (s, 2H), $1.53(\mathrm{~s}, 6 \mathrm{H}), 1.50(\mathrm{~s}, 6 \mathrm{H}), 1.45(\mathrm{~s}, 9 \mathrm{H}) .{ }^{13} \mathrm{C} \mathrm{NMR}\left(\mathrm{CDCl}_{3}\right) \delta 174.00,173.25,155.09,136.54$, $128.65,128.25,128.18,81.69,66.70,57.04,56.96,27.96,25.51,24.28$. ESI-MS: $[\mathrm{M}+\mathrm{Na}]^{+}$ calculated:401.2047; found: 401.2060.

Synthesis of Z-(Aib)3-COOtBu (2): Protected dipeptide 1 (5.5 g, $14 \mathrm{mmol}$ ) was dissolved in anhydrous methanol $(90 \mathrm{ml})$ and $10 \% \mathrm{Pd} / \mathrm{C}(20 \mathrm{mg})$ was added slowly to the reaction vessel, and the solution turned black. Then a $\mathrm{H}_{2}$ balloon was carefully fitted to the reaction vessel and allowed to stir for $16 \mathrm{~h}$ at room temperature. The $\mathrm{H}_{2}$ balloon was removed and the solution filtered through a Celite bed and the solvent was evaporated in vacuo to afford the free amine as a gummy solid and taken immediately into the next reaction without purification. Z-Aib-COOH (2.8 g, $12 \mathrm{mmol})$, $\operatorname{EDC} \cdot \mathrm{HCl}(2.73 \mathrm{~g}, 14 \mathrm{mmol}), \operatorname{HOAT}(1.93 \mathrm{~g}, 14 \mathrm{mmol})$ and NMM (2.2 ml, $14 \mathrm{mmol})$ were dissolved in anhydrous $\mathrm{CH}_{2} \mathrm{Cl}_{2}(50 \mathrm{ml})$, activate for $20 \mathrm{~min}$. The free amine was dissolved in anhydrous $\mathrm{CH}_{2} \mathrm{Cl}_{2}(20 \mathrm{ml})$, then added dropwise to above solution. The reaction stirred for $16 \mathrm{~h}$ at room temperature under $\mathrm{N}_{2}$. The solvent was evaporated in vacuo and the residue was redissolved in ethyl acetate $(100 \mathrm{ml})$ and washed with sat. $\mathrm{NH}_{4} \mathrm{Cl}(2 \times 80 \mathrm{ml})$, sat. $\mathrm{NaHCO}_{3}(2 \times 80 \mathrm{ml})$, DI water $(80 \mathrm{ml})$, brine $(80 \mathrm{ml})$, dried $\left(\mathrm{Na}_{2} \mathrm{SO}_{4}\right)$ and concentrated. Purified by column chromatography (50\%-70\% EtOAc/Hexanes) to give 2 as a white solid (5.8 g,89\%). ${ }^{1} \mathrm{H}$ NMR $\left(\mathrm{CDCl}_{3}\right) \delta 7.40-7.37$ (m, 5H), 7.10 (brs, 1H), 6.52 (brs, 1H), 5.20 (brs, 1H), 5.13 (s, 2H), 1.51 (s, 6H), 1.50 (s, 6H), 1.48 $(\mathrm{s}, 6 \mathrm{H}), 1.47(\mathrm{~s}, 9 \mathrm{H}) .{ }^{13} \mathrm{C} \mathrm{NMR}\left(\mathrm{CDCl}_{3}\right) \delta 173.89,173.05,172.81,155.45,136.22,128.81,128.57$, $128.30,80.87,67.15,57.38,56.92,56.61,28.02,25.54,25.34,24.63$. ESI-MS: $[\mathrm{M}+\mathrm{Na}]^{+}$ calculated: 486.2575; found. 486.2593 .

Synthesis of Z-(Aib)3-COOH (3): To a stirring solution of protected tripeptide 2 (3.1 g, $6.7 \mathrm{mmol})$ in anhydrous DCM $(70 \mathrm{ml})$, TFA $(70 \mathrm{ml})$ was added. The solution was stirred for $1.5 \mathrm{~h}$ at room temperature under $\mathrm{N}_{2}$. The solution remains colorless and clear. The solvent was evaporated and the remaining traces of TFA were removed by adding anhydrous diethyl ether $(3 \times 30 \mathrm{ml})$ and evaporation in vасио. The crude product was recrystallized from anhydrous diethyl ether to give carboxylic acid 3 as a white solid (2.4g,87\%). ${ }^{1} \mathrm{H}$ NMR $\left(\mathrm{CD}_{3} \mathrm{OD}\right) \delta 7.73$ (brs, $\left.1 \mathrm{H}\right), 7.63$ (brs, $\left.1 \mathrm{H}\right)$, 7.38-7.29 (m, 5H), $5.12(\mathrm{~s}, 2 \mathrm{H}), 1.45(\mathrm{~s}, 6 \mathrm{H}), 1.39(\mathrm{~s}, 6 \mathrm{H}), 1.36(\mathrm{~s}, 6 \mathrm{H}) .{ }^{13} \mathrm{C}$ NMR $\left(\mathrm{CD}_{3} \mathrm{OD}\right) \delta$ $178.44,176.42$, 176.26, 157.82, 138.41, 129.60, 129.09, 128.84, 67.53, 57.74, 57.63, 57.09, 25.35, 
25.34, 25.22. HRMS (ESI): calculated for $\mathrm{C}_{20} \mathrm{H}_{29} \mathrm{~N}_{3} \mathrm{O}_{6} \mathrm{Na}, 430.1949$ [M+Na] $]^{+}$; found: 430.1969 $[\mathrm{M}+\mathrm{Na}]^{+}$

Synthesis of Z-(Aib)-COOtBu (6): Protected tripeptide 2 (2.4 g, $5.2 \mathrm{mmol})$ was dissolved in anhydrous methanol $(70 \mathrm{ml})$ and $10 \% \mathrm{Pd} / \mathrm{C}(50 \mathrm{mg})$ was added slowly to the reaction vessel. Then a $\mathrm{H}_{2}$ balloon was carefully fitted to the reaction vessel and allowed to stir vigorously for $16 \mathrm{~h}$ at room temperature. The $\mathrm{H}_{2}$ balloon was removed and the solution filtered through a Celite bed and the solvent was removed in vacuo to afford free amine $\mathbf{5}$ as a gummy solid which was immediately used in next reaction without purification. In a separate flask, to a solution of $\mathbf{3}(2.4 \mathrm{~g}, 5.2 \mathrm{mmol})$ in $3 \mathrm{ml}$ of anhydrous acetonitrile, cooled to $0^{\circ} \mathrm{C}$, was added $\mathrm{EDC} \cdot \mathrm{HCl}(1 \mathrm{~g}, 5.2 \mathrm{mmol})$, the cooling bath was removed, the solution was let reach room temperature and then stirred at room temperature for 30 min under $\mathrm{N}_{2}$. The solvent was evaporated in vacuo and the residue was dissolved in ethyl acetate $(200 \mathrm{ml})$ and washed with $10 \% \mathrm{KHSO}_{4}(200 \mathrm{ml})$, dried $\left(\mathrm{Na}_{2} \mathrm{SO}_{4}\right)$ and evaporated in vacuo to obtain the oxazolone $\mathbf{4}$ as an oily residue which was immediately dissolved in $60 \mathrm{ml}$ of anhydrous acetonitrile. To this solution, was added the free amine $5 \mathrm{in} 70 \mathrm{ml}$ anhydrous acetonitrile. After stirring for 3 days at $80^{\circ} \mathrm{C}$ under reflux and $\mathrm{N}_{2}$, the solvent was evaporated to dryness in vacuo. The solid crude residue was purified by column chromatography (50\%-75\% EtOAc/Hexanes) to give $\mathrm{Z}$-(Aib) ${ }_{6}-\mathrm{COOtBu}$ as a white solid (2.9g, $77 \%$ yield). ${ }^{1} \mathrm{H}$ NMR $\left(\mathrm{CDCl}_{3}\right)$ $\delta 7.46$ (brs, 1H), 7.43-7.34 (m, 7H), 7.25 (brs, 1H), 6.31 (brs, 1H), 5.31 (brs, 1H), 5.12 (s, 2H), $1.51(\mathrm{~s}, 6 \mathrm{H}), 1.48(\mathrm{~s}, 6 \mathrm{H}), 1.47(\mathrm{~s}, 12 \mathrm{H}), 1.44(\mathrm{~s}, 6 \mathrm{H}), 1.44(\mathrm{~s}, 9 \mathrm{H}) 1.31(\mathrm{~s}, 6 \mathrm{H}) .{ }^{13} \mathrm{C} \mathrm{NMR}\left(\mathrm{CDCl}_{3}\right)$ $\delta 174.99,174.19,174.12,174.04,173.80,156.01,136.19,128.68,128.56,128.16,79.71,67.33$, 57.24, 56.83, 56.73, 56.61, 56.46, 56.02, 27.91, 25.50, 25.42, 25.22, 25.07, 24.96, 24.87. ESI-MS: [M+Na $]^{+}$calculated: 741.4157; found: 741.4111 . 


\section{1c. Synthesis of di-tert-butyl 5-(azidomethyl)isophthalate}

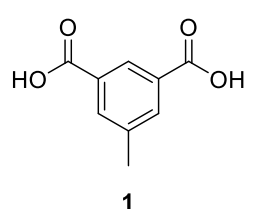

diethyl phosphite
$\underset{\text { DIPEA, THF, N }}{2}$
$0^{\circ} \mathrm{C} \rightarrow \mathrm{rt}, 24 \mathrm{~h}$ $77 \%$

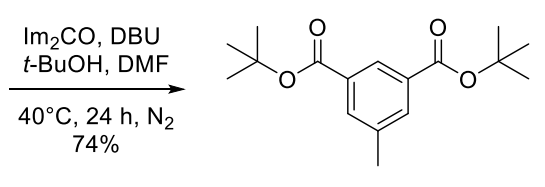

2

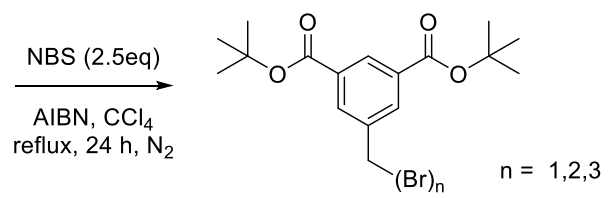

3
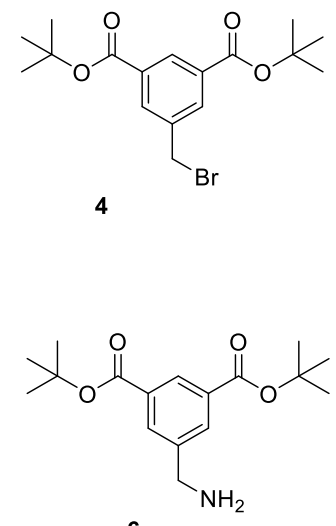

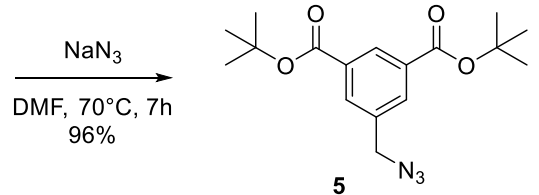

$\underset{0^{\circ} \mathrm{C} \rightarrow \mathrm{rt}, 18.5 \mathrm{~h}}{\stackrel{\mathrm{PPh}_{3}, \mathrm{THF}, \mathrm{H}_{2} \mathrm{O}}{\longrightarrow}}$ $54 \%$

Scheme S2. Synthesis of di-tert-butyl 5-(azidomethyl)isophthalate

Synthesis of di-tert-butyl 5-methylisophthalate (2): ${ }^{3} \quad$ 1,1'-carbonyldiimidazole (992 mg, 6.12 mmol) was added to a solution of 5-methylisophthalic acid $(1,500 \mathrm{mg}, 2.78 \mathrm{mmol})$ in anhydrous DMF (4.6 mL). The pale yellow solution was heated to $40{ }^{\circ} \mathrm{C}$ under Ar for $1.5 \mathrm{~h}$. DBU (0.91 mL, $6.12 \mathrm{mmol})$ followed shortly by $t$-BuOH $(1.12 \mathrm{~mL}, 12.23 \mathrm{mmol})$ were then injected upon which the solution turned from yellow to red/brown. After $17 \mathrm{~h}$ the solution was cooled to room temperature, diluted with $\mathrm{CH}_{2} \mathrm{Cl}_{2}$ and concentrated under high vacuum to a dark red oil. The dark red oil was again diluted in $\mathrm{CH}_{2} \mathrm{Cl}_{2}$, acidified ( $\mathrm{HCl}(\mathrm{aq}) 1.5 \mathrm{M}$ ) and the aqueous layer extracted with $\mathrm{CH}_{2} \mathrm{Cl}_{2}$ (until no spot visible on TLC). The combined organic layers were washed with water, and $10 \% \mathrm{~K}_{2} \mathrm{CO}_{3}$ (turns from pale yellow to light red color upon addition of $\mathrm{K}_{2} \mathrm{CO}_{3}$ ), then dried with $\mathrm{Na}_{2} \mathrm{SO}_{4}$ and concentrated under vacuum to a red solid. The crude product was purified by column chromatography (short column/silica plug) (silica gel, hexanes: ethyl acetate $=5: 1$ ) yielding target compound as a crystalline white solid $(630 \mathrm{mg}, 77 \%) .{ }^{1} \mathrm{H} \mathrm{NMR}\left(\mathrm{CDCl}_{3}\right) \delta 8.37(\mathrm{~s}, 1 \mathrm{H}), 7.95(\mathrm{~s}$, 2H), 2.43 (s, 3H), $1.60(\mathrm{~s}, 18 \mathrm{H}) .{ }^{13} \mathrm{C} \mathrm{NMR}\left(\mathrm{CDCl}_{3}\right) \delta 165.47,138.33,133.96,132.32,127.87$, 81.54, 28.33, 21.31. GC-MS: $\mathrm{m} / \mathrm{z}(\%)=292(.16)\left[\mathrm{M}^{+}\right], 237(21)\left[\mathrm{M}^{+}-\mathrm{C}\left(\mathrm{CH}_{3}\right)_{3}^{+}\right], 181(100)\left[\mathrm{M}^{+}-\right.$ $\left.\left(\mathrm{C}\left(\mathrm{CH}_{3}\right)_{3}\right)_{2}^{+}\right]$. 
Synthesis of di-tert-butyl 5-(bromomethyl)isophthalate (4): ${ }^{4}$ A flame dry two neck r.b. flask equipped with magnetic stirrer and condenser was charged with a $\mathrm{CCl}_{4}$ solution $(10 \mathrm{~mL})$ of di-tertbutyl 5-methylisophthalate $(2,865 \mathrm{mg}, 2.96 \mathrm{mmol})$ under $\mathrm{N}_{2} . N$-bromosuccinimide (NBS, 1.316g, $7.40 \mathrm{mmol}, 2.5 \mathrm{eq}$ ) was added followed by 2,2'-azobis(2-methylpropionitrile) (AIBN, $24.3 \mathrm{mg}$, $0.148 \mathrm{mmol}, 5 \%)$. The flask was evacuated and purged with $\mathrm{N}_{2}$ three times and mixture refluxed for $24 \mathrm{~h}$ under $\mathrm{N}_{2}$. The cooled residue was diluted in carbon tetrachloride and washed with $10 \%$ sodium thiosulphate aquous solution. The organic phase was dried over anhydrous $\mathrm{MgSO}_{4}$, filtered and the solvent removed in vacuo. Column chromatography (silica gel, hexanes: ethyl acetate $=$ 50:1) afforded mono brominated (4 mass \%), dibrominated (68 mass \%) and tribrominated (28 mass \%) derivatives as white solids (mixture 3). Attempts to synthesize directly 4 using a stoichiometric amount of NBS were not successful, as $<10 \%$ yields were always obtained, hence the use of excess NBS followed by debromination. di-tert-butyl 5-(bromomethyl)isophthalate (4). ${ }^{1} \mathrm{H}$ NMR (600 MHz, Chloroform- $d$ ) $\delta 8.49$ (s, 1H), 8.15 (s, 2H), 4.54 (s, 2H), 1.61 (s, 18H). di-tert-butyl 5-(dibromomethyl)isophthalate ${ }^{1} \mathrm{H} \mathrm{NMR}\left(\mathrm{CDCl}_{3}\right) \delta 8.51(\mathrm{~s}, 1 \mathrm{H}), 8.32(\mathrm{~s}, 2 \mathrm{H}), 6.70$ (s, $1 \mathrm{H}), 1.62(\mathrm{~s}, 18 \mathrm{H}) .{ }^{13} \mathrm{C}$ NMR $\left(\mathrm{CDCl}_{3}\right) \delta 164.22,142.59,133.12,131.65,131.20,82.38,39.26$, 28.29. di-tert-butyl 5-(tribromomethyl)isophthalate ${ }^{1} \mathrm{H} \mathrm{NMR}\left(500 \mathrm{MHz}, \mathrm{CDCl}_{3}\right) \delta 8.77$ (s, $\left.2 \mathrm{H}\right)$, $8.51(\mathrm{~s}, 1 \mathrm{H}), 1.63(\mathrm{~s}, 18 \mathrm{H})$.

A flame dry two neck r.b. flask equipped with magnetic stirrer was charged with an anhydrous THF solution (5 mL) of di-tert-butyl 5-(dibromomethyl)isophthalate (496 mg, 1.10 mmol) under $\mathrm{N}_{2}$. The mixture was stirred in an ice bath for 25 mins at which point $\mathrm{N}, \mathrm{N}$ diisopropylethylamine (DIPEA, $0.77 \mathrm{~mL}, 4.41 \mathrm{mmol}, 4 \mathrm{eq}$ ) followed by diethyl phosphite $(0.57$ $\mathrm{mL}, 4.41 \mathrm{mmol}, 4 \mathrm{eq}$ ) was injected. The mixture was slowly warmed to room temperature and was stirred for $22 \mathrm{~h}$ (monitored by TLC). The reaction was quenched with $\mathrm{H}_{2} \mathrm{O}(15 \mathrm{~mL})$, and concentrated under vacuum to remove THF. The residual aqueous mixture was extracted with EtOAc, washed with saturated $\mathrm{NH}_{4} \mathrm{CL}$, dried over anhydrous $\mathrm{MgSO}_{4}$, filtered and the solvent removed in vacuo. Column chromatography (silca gel, hexanes: ethyl acetate $=20: 1$ ) afforded 4 as a white solid (286 mg, 70\%). ${ }^{1} \mathrm{H}$ NMR $\left(\mathrm{CDCl}_{3}\right) \delta 8.49(\mathrm{~s}, 1 \mathrm{H}), 8.15(\mathrm{~s}, 2 \mathrm{H}), 4.54(\mathrm{~s}, 2 \mathrm{H}), 1.61$ (s, $18 \mathrm{H}) .{ }^{13} \mathrm{C} \mathrm{NMR}\left(\mathrm{CDCl}_{3}\right) \delta 164.65,138.45,133.75,133.12,130.50,82.06,32.07,28.30$.

Syntesis of di-tert-butyl 5-(azidomethyl)isophthalate (5): ${ }^{5}$ A flame dry two neck r.b. flask equipped with magnetic stirrer was charged with with an anhydrous dimethylformamide (DMF) 
solution (3 mL) of di-tert-butyl 5-(bromomethyl)isophthalate (273 mg, $0.735 \mathrm{mmol}$ ) under $\mathrm{N}_{2}$. Sodium azide (143 mg, $2.21 \mathrm{mmol}, 3 \mathrm{eq}$ ) was added and the mixture was evacuated and purged with $\mathrm{N}_{2}$ three times. The mixture was stirred at $70^{\circ} \mathrm{C}$ for $7 \mathrm{~h}$. The cooled mixture was quenched with $\mathrm{H}_{2} \mathrm{O}(5 \mathrm{~mL})$ and extracted with EtOAc. The organic layer was washed with brine, dried over anhydrous $\mathrm{Na}_{2} \mathrm{SO}_{4}$, filtered and the solvent removed in vacuo to afford the product as a yellow oil (245 mg, 100\%). ${ }^{1} \mathrm{H}$ NMR $\left(\mathrm{CDCl}_{3}\right) \delta 8.53(\mathrm{~s}, 1 \mathrm{H}), 8.09$ (s, 2H), $4.45(\mathrm{~s}, 2 \mathrm{H}), 1.61(\mathrm{~s}, 18 \mathrm{H}) .{ }^{13} \mathrm{C}$ NMR $\left(\mathrm{CDCl}_{3}\right) \delta 164.78,136.20,133.09,132.84,130.43,82.06,54.24,28.31$. IR (FTIR-ATR): (C-H) 3004, 2974, 2929, (N=N) 2091, (C=O) $1705 \mathrm{~cm}^{-1}$

Synthesis of di-tert-butyl 5-(aminomethyl)isophthalate (6): ${ }^{6}$ This compound was prepared according to literature procedure. A flame dry two neck r.b. flask equipped with magnetic stirrer was charged with a solution of distilled (sodium, benzophenone) tetrahydrofuran (THF, $1 \mathrm{~mL}$ ) and azido derivative $(\mathbf{5}, 110 \mathrm{mg}, 0.330 \mathrm{mmol})$ under $\mathrm{N}_{2}$. The mixture was stirred in an ice bath for 30 min. Triphenylphosphine $(130 \mathrm{mg}, 0.495 \mathrm{mmol})$ was added in 5 equal portions over 5 mins. (effervescence was observed for approx.1 h) The mixture was slowly allowed to reach room temperature while stirring under $\mathrm{N}_{2}$ for $18.5 \mathrm{~h}$ (monitored by TLC). $\mathrm{H}_{2} \mathrm{O}$ ( $1 \mathrm{~mL}$ ) was added and the mixture was stirred for an additional hour. The solvent removed in vacuo to afford the crude product as a clear oil. Column chromatography (silca gel, dichloromethane: methanol = 98:2) afforded the product as a white solid $(50 \mathrm{mg}, 50 \%) .{ }^{1} \mathrm{H} \mathrm{NMR}\left(\mathrm{CDCl}_{3}\right) \delta 8.46(\mathrm{~s}, 1 \mathrm{H}), 8.10(\mathrm{~s}, 2 \mathrm{H})$, $3.97(\mathrm{~s}, 2 \mathrm{H}), 1.71(\mathrm{~s}, 2 \mathrm{H}), 1.61(\mathrm{~s}, 18 \mathrm{H}) .{ }^{13} \mathrm{C} \mathrm{NMR}\left(\mathrm{CDCl}_{3}\right) \delta 165.28,143.61,132.67,132.07$, 129.18, 81.74, 46.07, 28.32. IR (FTIR-ATR): (N-H) 3391, 3323, (C-H) 2982, 2933, 2885, (C=O) $1699 \mathrm{~cm}^{-1}$ 


\section{Binding groups reactivity.}

\section{2a. XPS/UPS}

Figure S1 shows UPS VB spectra measured for the $\mathrm{TiO}_{2}(110)$ surfaces exposed to each peptide solution. These experimental spectra were compared to a DOS calculated for the two molecules, weighted by the photoemission cross section for the corresponding photon energy $(\mathrm{He} 2=40.8 \mathrm{eV})$. It is clear also from the VB spectra, that the measured electronic structure is much closer to the expected one for Z-(Aib) ${ }_{6}$-Ipa than for Z-(Aib) $)_{6}-\mathrm{COOH}$ because the lower coverage of the latter allows for the presence of more surface contaminants.
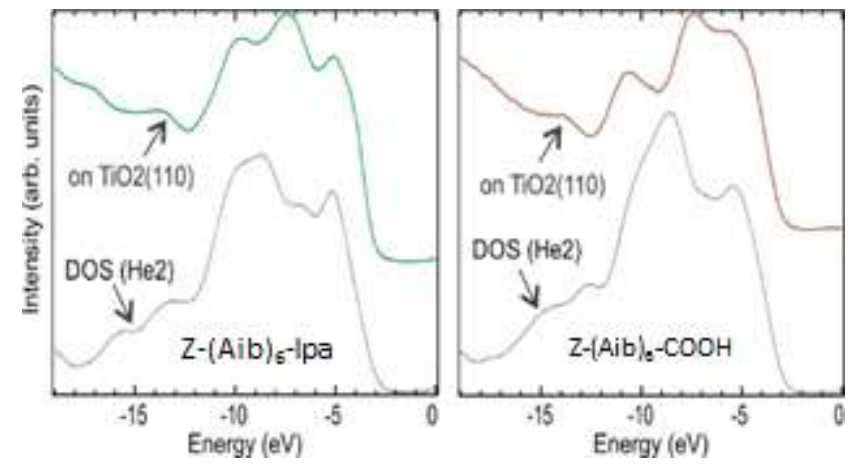

Figure S1. UPS VB spectra of a $\mathrm{TiO}_{2}(110)$ surface exposed to Z-(Aib) ${ }_{6}-\mathrm{COOHor} \mathrm{Z-(Aib)6-Ipa,}$ compared to the UPS-weighted DOS for each compound.

2b. FTIR
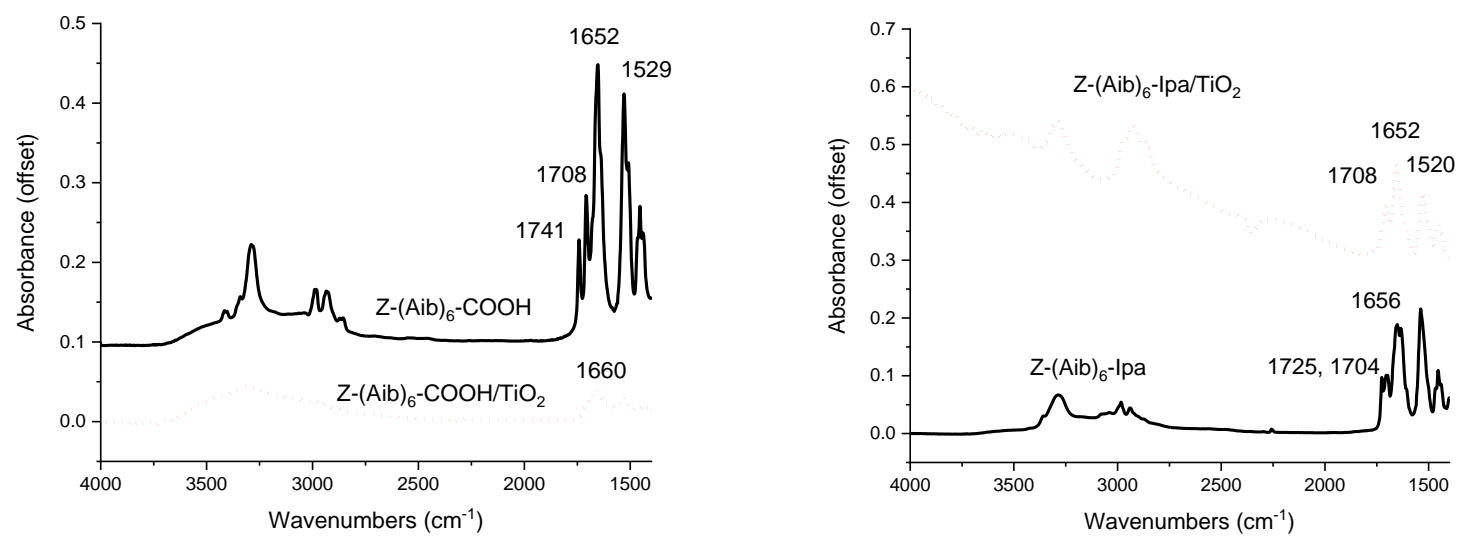

Figure S2. FTIR-ATR spectrum of neat Z-(Aib) ${ }_{6}-\mathrm{COOH}$ (black, solid line) and representative single pixel FTIR spectrum of Z-(Aib) ${ }_{6}-\mathrm{OH} / \mathrm{TiO}_{2}$ (red, dotted line); FTIR-ATR spectrum of neat Z-(Aib) $6^{-I p a}$ (black, solid line) and representative single pixel FTIR spectrum of Z-(Aib) $6^{-}$ $\mathrm{Ipa} / \mathrm{TiO}_{2}$ (red, dotted line). 


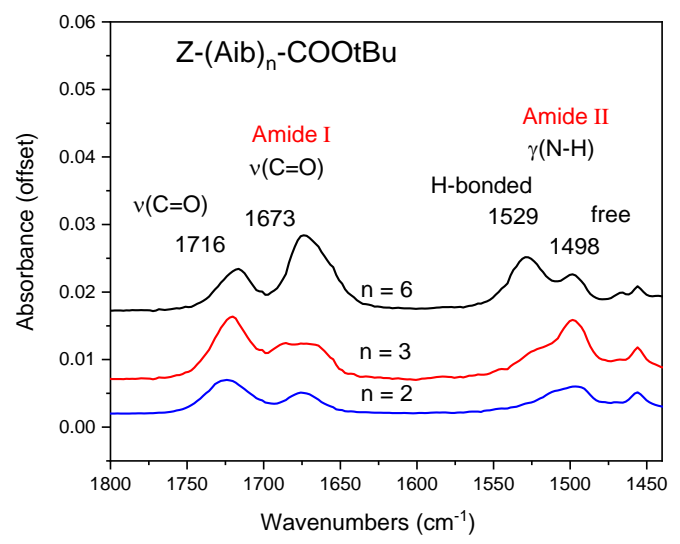

Figure S3. The $1800-1420 \mathrm{~cm}^{-1}$ spectral region of the FTIR spectra of Z-(Aib) ${ }_{n}-\mathrm{COOtBu}(\mathrm{n}=2,3$ and 6) solutions $\left(5 \mathrm{mM}, \mathrm{CHCl}_{3}\right)$

In the $1800-1420 \mathrm{~cm}^{-1}$ region in FigureS3, the broad $1716 \mathrm{~cm}^{-1}$ band, assigned to the $\mathrm{C}=\mathrm{O}$ in the ester and $\mathrm{Z}$ group, remains mostly unchanged relative to the amide-I band at $1673 \mathrm{~cm}^{-1}$, which instead increases in intensity as the peptide chain length increases. ${ }^{51}$ The amide-II bands at 1529 and $1498 \mathrm{~cm}^{-1}$ mainly arise from the $\mathrm{N}-\mathrm{H}$ bending and $\mathrm{C}-\mathrm{N}$ stretching, respectively, which are coupled vibrational modes. The $\mathrm{C}=\mathrm{O} \cdots \mathrm{H}-\mathrm{N}$ hydrogen bond results in a significant change of the amide-II band, from a broad shoulder at about $1510 \mathrm{~cm}^{-1}$ in Z-(Aib) $)_{3}-\mathrm{COOtBu}$ to a band at higher energy $\left(1529 \mathrm{~cm}^{-1}\right)$ with increased intensity in $\mathrm{Z}-(\mathrm{Aib})_{6}-\mathrm{COOtBu}{ }^{51}$

Binding to nanostructured $\mathrm{TiO}_{2}$ films. The binding to $\mathrm{TiO}_{2}$, and any difference in surface coverage between $\mathrm{Z}-(\mathrm{Aib})_{6}-\mathrm{COOH}$ and $\mathrm{Z}$-(Aib) 6 -Ipa, onto nanostructured $\mathrm{TiO}_{2}$ anatase thin films was probed using FTIR microscopic imaging.

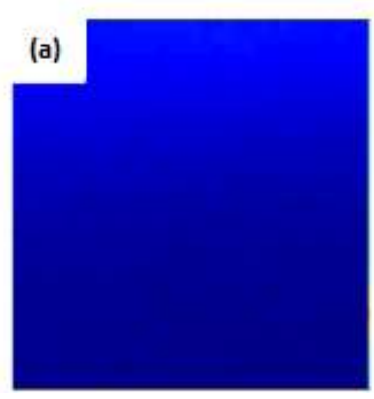

Z-(Aib)6-COOH/TiO2

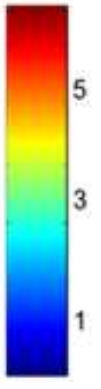

(b)

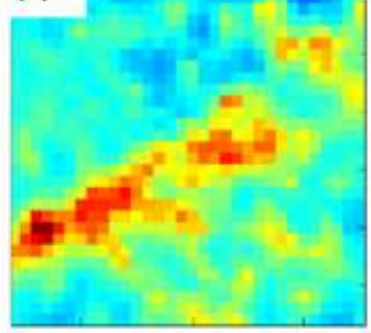

Z-(Aib)6-Ipa/TiO2

Figure S4. . FTIR image of the integrated band area of the region $1686-1568 \mathrm{~cm}^{-1}( \pm S T D)$ of (a) Z-(Aib) $6-\mathrm{COOH} / \mathrm{TiO}{ }_{2}$ (Image dimensions: $100 \times 100 \mu \mathrm{m}^{2}$ ) and (b) Z-(Aib) ${ }_{6}-\mathrm{Ipa} / \mathrm{T} \mathrm{iO}{ }_{2}$ (Image dimensions: $100 \times 100 \mu \mathrm{m}^{2}$ ).

FTIR images of the films shows that Z-(Aib) ${ }_{6}-\mathrm{COOH}$ binds much more weakly than Z-(Aib)6-Ipa. This is shown in Figure $\mathrm{S} 4$, where $100 \times 100 \mu \mathrm{m}^{2}$ areas of the $\mathrm{TiO}_{2}$ nanostructured films are shown for $\mathrm{Z}-(\mathrm{Aib})_{6}-\mathrm{COOH} / \mathrm{TiO}_{2}$ (Figure S4(a)) and $\mathrm{Z}-(\mathrm{Aib})_{6}-\mathrm{Ipa} / \mathrm{TiO}_{2}($ Figure S4(b)). These images, 
shown on the same intensity scale, were obtained by integrating the area under the Amide-I band $v(\mathrm{C}=\mathrm{O})$, in the $1686-1568 \mathrm{~cm}^{-1}$ range. While the images exhibit inhomogeneities typical of this type of nanostructured films, they clearly show that the $\mathrm{Z}$-(Aib) 6 - $\mathrm{Ipa}_{\mathrm{TiO}}$ films have a much higher surface coverage than that of $\mathrm{Z}-(\mathrm{Aib})_{6}-\mathrm{COOH} / \mathrm{TiO}_{2}$ films. The image of $\mathrm{Z}-(\mathrm{Aib})_{6}-$ $\mathrm{COOH} / \mathrm{TiO}_{2}$ of Figure S4(a) appears homogenous only because the coverage is at a very low detection limit, as the scale for both images is the same. Measurements made at different locations on the $\mathrm{Z}-(\mathrm{Aib})_{6}-\mathrm{COOH} / \mathrm{TiO}_{2}$ and $\mathrm{Z}-(\mathrm{Aib})_{6}-\mathrm{Ipa} / \mathrm{TiO}_{2}$ films produced similar spectra.

\section{3. ${ }^{1} \mathrm{H}$ NMR characterization of peptides}

The NH proton resonances were assigned according to the $\mathrm{NH}(\mathrm{i}) \rightarrow \mathrm{NH}(\mathrm{i}+1)$ through-space connectivity acquired from 2D NOESY experiments, Figure S3. A section of the NOESY spectrum is shown in Figure $\mathrm{S} 1 \mathrm{All} \mathrm{NH}(\mathrm{i}) \rightarrow \mathrm{NH}(\mathrm{i}+1)$ cross-peaks are indicative of a folded structure of peptide $\mathrm{Z}-(\mathrm{Aib})_{6}-\mathrm{COOtBu}^{7}$.

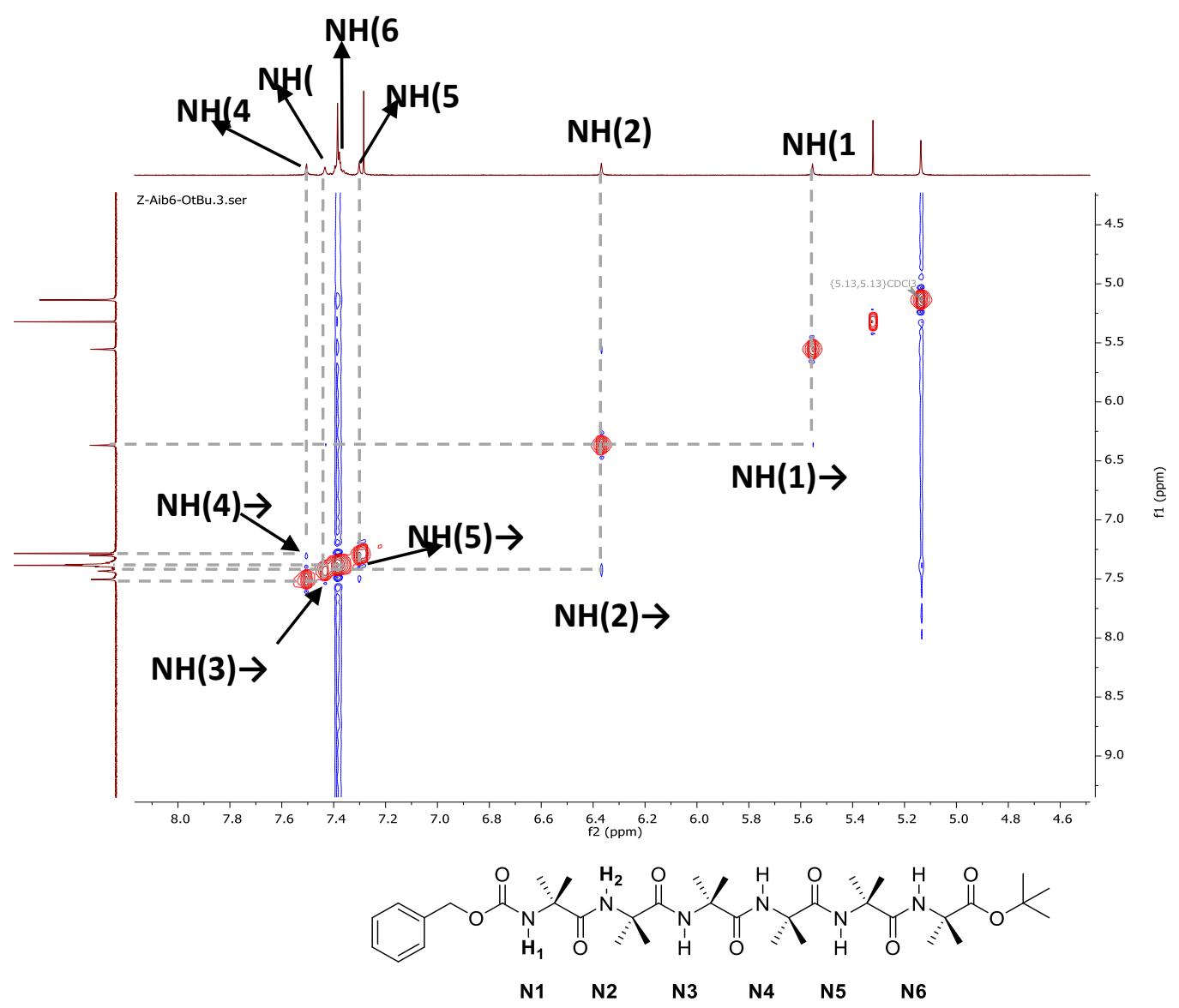

Figure S5. Selected region of the NOESY spectrum of Z-(Aib) ${ }_{6}-\mathrm{COOtBu}$ in $\mathrm{CDCl}_{3}$ solution (peptide concentration: $5 \mathrm{mM})$. The $\mathrm{NH}(\mathrm{i}) \rightarrow \mathrm{NH}(\mathrm{i}+1)$ cross-peaks are indicated. 


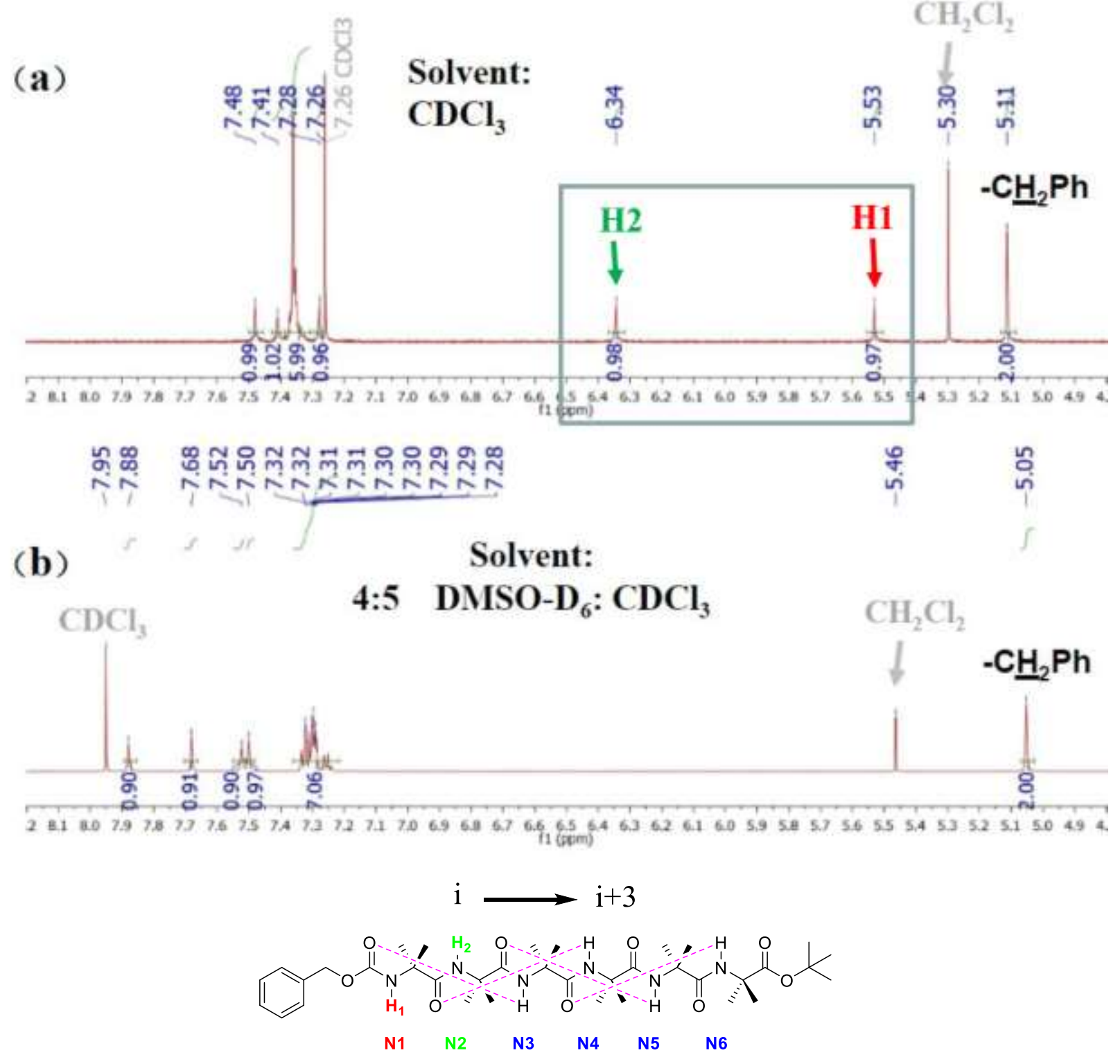

Figure S6. Solvent effect on the NH chemical shifts, ${ }^{1} \mathrm{HNMR}$ for the Z-(Aib) ${ }_{6}-\mathrm{COOtBu}$ in (a) $\mathrm{CDCl}_{3}$, (b) 4:5 (CD $)_{2} \mathrm{SO}$ (DMSO-d6): $\mathrm{CDCl}_{3}$

A solvent titration experiment of the NH chemical shifts, shown in Figure S4, was carried out to probe which NH groups are not hydrogen bonded. Briefly, the ${ }^{1} \mathrm{H}$ NMR spectrum of Z(Aib) $)_{6}-\mathrm{COOtBu}$ following the addition of $\left(\mathrm{CD}_{3}\right)_{2} \mathrm{SO}$, a $\mathrm{H}$-bond accepting solvent, and in $\mathrm{CDCl}_{3}$, a poor H-bond accepting solvent, showed large downfield shifts of, moving to 7.3 -7.9 ppm region upon addition of DMSO only of $\mathrm{NH}(1)\left(\delta=5.53 \mathrm{ppm}\right.$ in $\left.\mathrm{CDCl}_{3}\right)$ and $\mathrm{NH}(2)(\delta=6.34 \mathrm{ppm}$ in $\mathrm{CDCl}_{3}$ ), whereas the other $\mathrm{NH}$ were mostly unchanged. This indicates that only the first two NH 
protons on the $\mathrm{Z}$ end were solvent-exposed and not involved in intramolecular hydrogen bonding, suggesting either partial unfolding only of the Z-protected end but helical structure of the peptide, and consistent with the $3^{10}$-helical model which involves $\mathrm{i} \rightarrow \mathrm{i}+3$ hydrogen bonding.

HMBC correlations were inconclusive, as for every amide proton only one correlation with the carbon of the $\mathrm{C}=\mathrm{O}$ group in the same $\mathrm{Aib}$ residue (intra-residue correlation) was observed, and not the needed inter-residue correlation, except for the two ends.

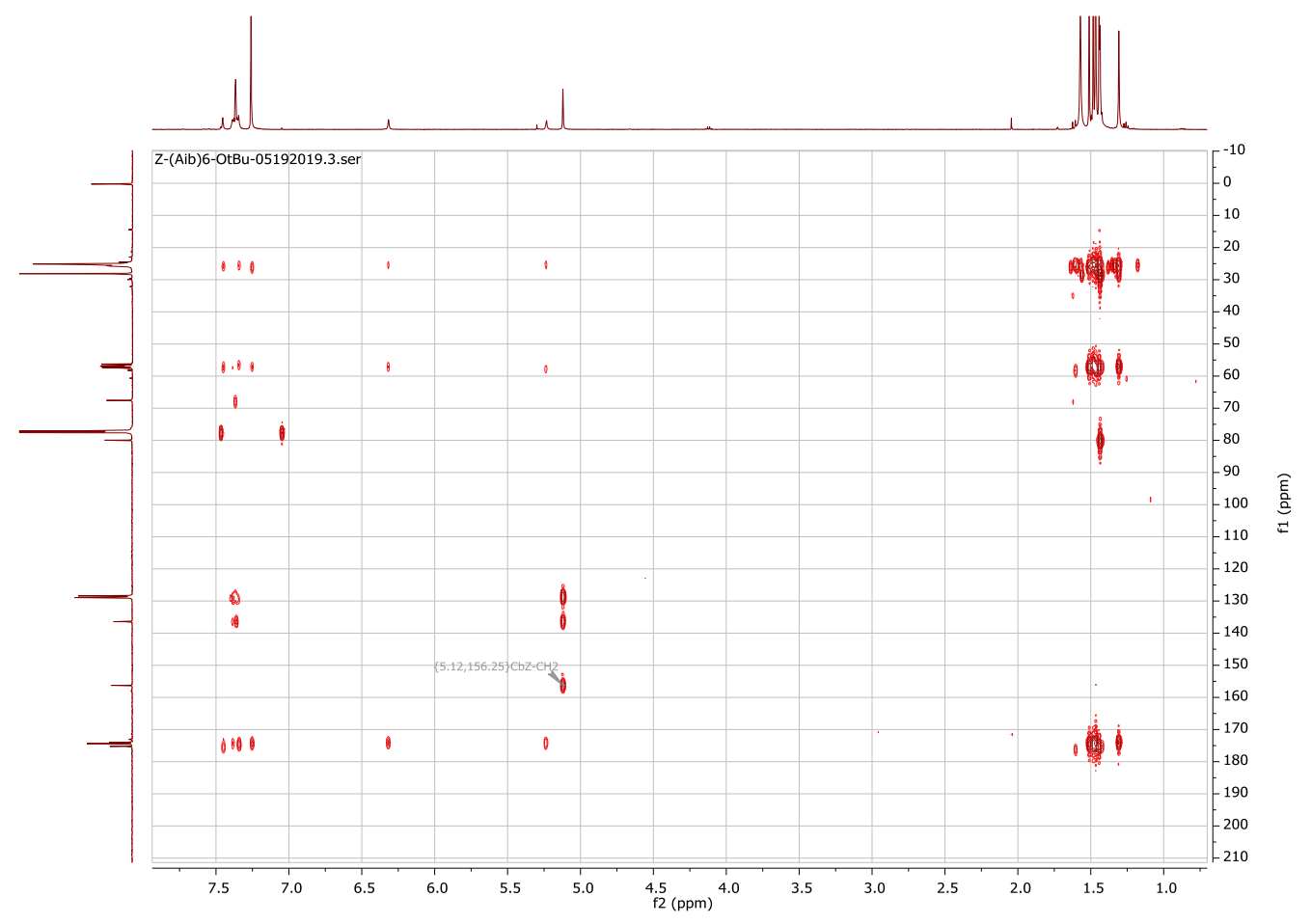

\begin{tabular}{|l|l|l|l|l|l|}
\hline $5.12 \leftrightarrow 156.25$ & $5.12 \leftrightarrow 136.42$ & $5.12 \leftrightarrow 128.80$ & $5.12 \leftrightarrow 67.56$ & $1.31 \leftrightarrow 174.05$ & $1.31 \leftrightarrow 56.85$ \\
\hline $1.31 \leftrightarrow 25.65$ & $1.51 \leftrightarrow 174.37$ & $1.44 \leftrightarrow 175.24$ & 1.47 (right) $\leftrightarrow 174.29$ & $1.44 \leftrightarrow 79.95$ & $5.23 \leftrightarrow 174.29$ \\
\hline $5.23 \leftrightarrow 57.47$ & $1.44($ left $) \leftrightarrow 57.07$ & $6.32 \leftrightarrow 56.85$ & $6.32 \leftrightarrow 174.05$ & $7.45 \leftrightarrow 175.24$ & $7.26 \leftrightarrow 174.37$ \\
\hline $7.34 \leftrightarrow 174.43$ & $7.38 \leftrightarrow 174.37$ & $7.36 \leftrightarrow 67.56$ & $7.45 \leftrightarrow 56.97$ & $7.38 \leftrightarrow 57.07$ & $7.34 \leftrightarrow 56.26$ \\
\hline $7.26 \leftrightarrow 56.70$ & 1.47 (left) $\leftrightarrow 174.37$ & $1.48 \leftrightarrow 174.43$ & 1.47 (right) $\leftrightarrow 57.47$ & $1.51 \leftrightarrow 56.97$ & $1.48 \leftrightarrow 56.26$ \\
\hline 1.47 (left) $\leftrightarrow 56.70$ & & & & & \\
\hline
\end{tabular}

Figure S7. HMBC correlation for $\mathrm{Z}-(\mathrm{Aib})_{6}-\mathrm{COOtBu}$ 


\section{References}

1. Gottlieb, H. E.; Kotlyar, V.; Nudelman, A., NMR chemical shifts of common laboratory solvents as trace impurities. The Journal of organic chemistry 1997, 62 (21), 7512-7515.

2. Kaplan, J. M.; Shang, J.; Gobbo, P.; Antonello, S.; Armelao, L.; Chatare, V.; Ratner, D. M.; Andrade, R. B.; Maran, F., Conformationally constrained functional peptide monolayers for the controlled display of bioactive carbohydrate ligands. Langmuir 2013, 29 (26), 8187-8192.

3. Davis, B. G.; Shang, X.; DeSantis, G.; Bott, R. R.; Jones, J. B., The controlled introduction of multiple negative charge at single amino acid sites in subtilisin Bacillus lentus. Bioorganic \& Medicinal Chemistry 1999, 7 (11), 2293-2301.

4. Hosono, N.; Gochomori, M.; Matsuda, R.; Sato, H.; Kitagawa, S., Metal-Organic Polyhedral Core as a Versatile Scaffold for Divergent and Convergent Star Polymer Synthesis. Journal of the American Chemical Society 2016, 138 (20), 6525-6531.

5. Smith, J. M.; Vitali, F.; Archer, S. A.; Fasan, R., Modular Assembly of Macrocyclic Organo-Peptide Hybrids Using Synthetic and Genetically Encoded Precursors. Angewandte Chemie International Edition 2011, 50 (22), 5075-5080.

6. Behera, H.; Ramkumar, V.; Madhavan, N., Cation-Transporting Peptides: Scaffolds for Functionalized Pores? Chemistry - A European Journal 2015, 21 (28), 10179-10184.

7. Fabris, L.; Antonello, S.; Armelao, L.; Donkers, R. L.; Polo, F.; Toniolo, C.; Maran, F., Gold nanoclusters protected by conformationally constrained peptides. Journal of the American Chemical Society 2006, 128 (1), 326-336. 


\section{Appendix}

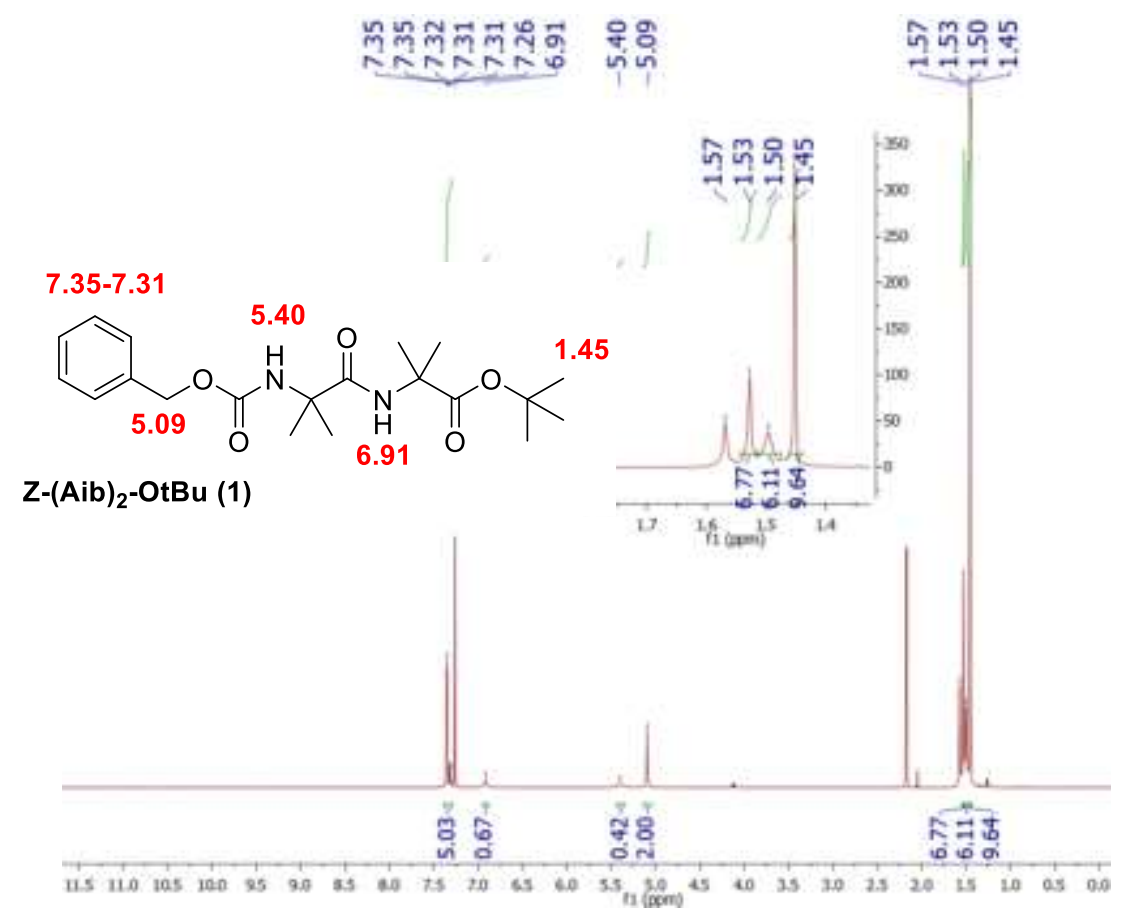

Fig. S8 ${ }^{1} \mathrm{H}$ NMR of Z-(Aib) $)_{2}-\mathrm{COOtBu}$ in $\mathrm{CDCl}_{3}$ and proposed assignments

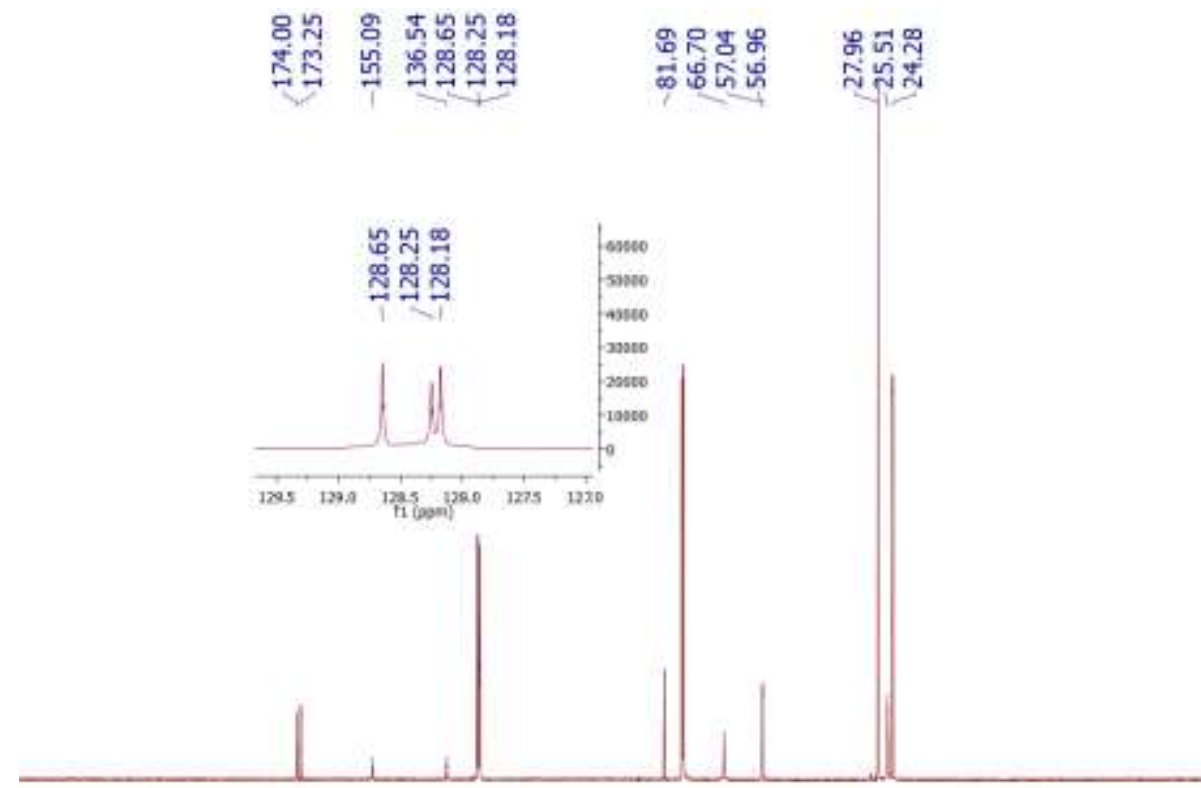

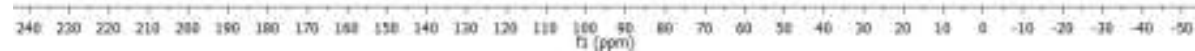

Fig. S9 ${ }^{13} \mathrm{C}$ NMR of $\mathrm{Z}-(\mathrm{Aib})_{2}-\mathrm{COOtBu}$ in $\mathrm{CDCl}_{3}$ 


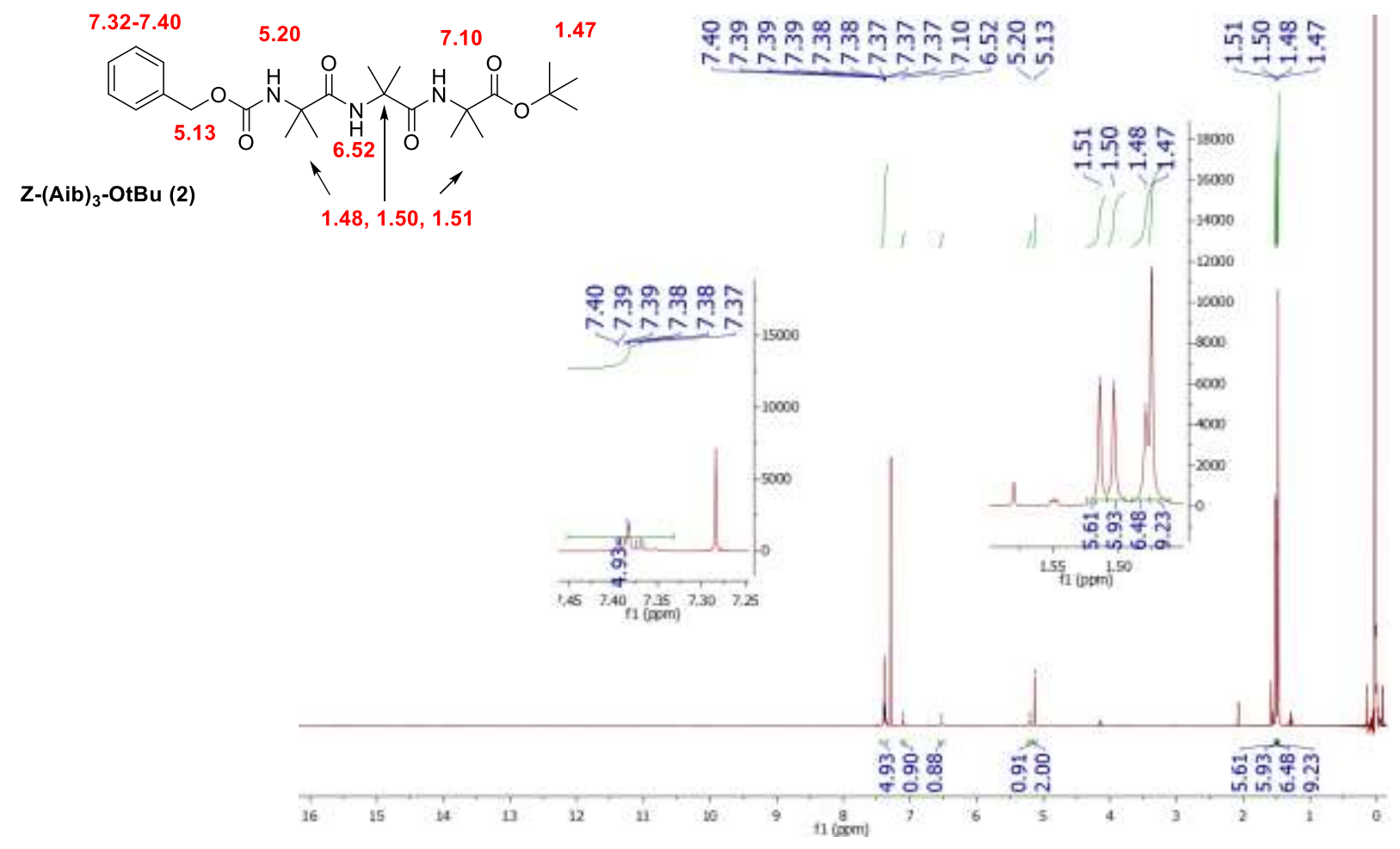

Fig. S10 ${ }^{1} \mathrm{H}$ NMR of Z-(Aib) ${ }_{3}-\mathrm{COOtBu}$ in $\mathrm{CDCl}_{3}$ and proposed assignments

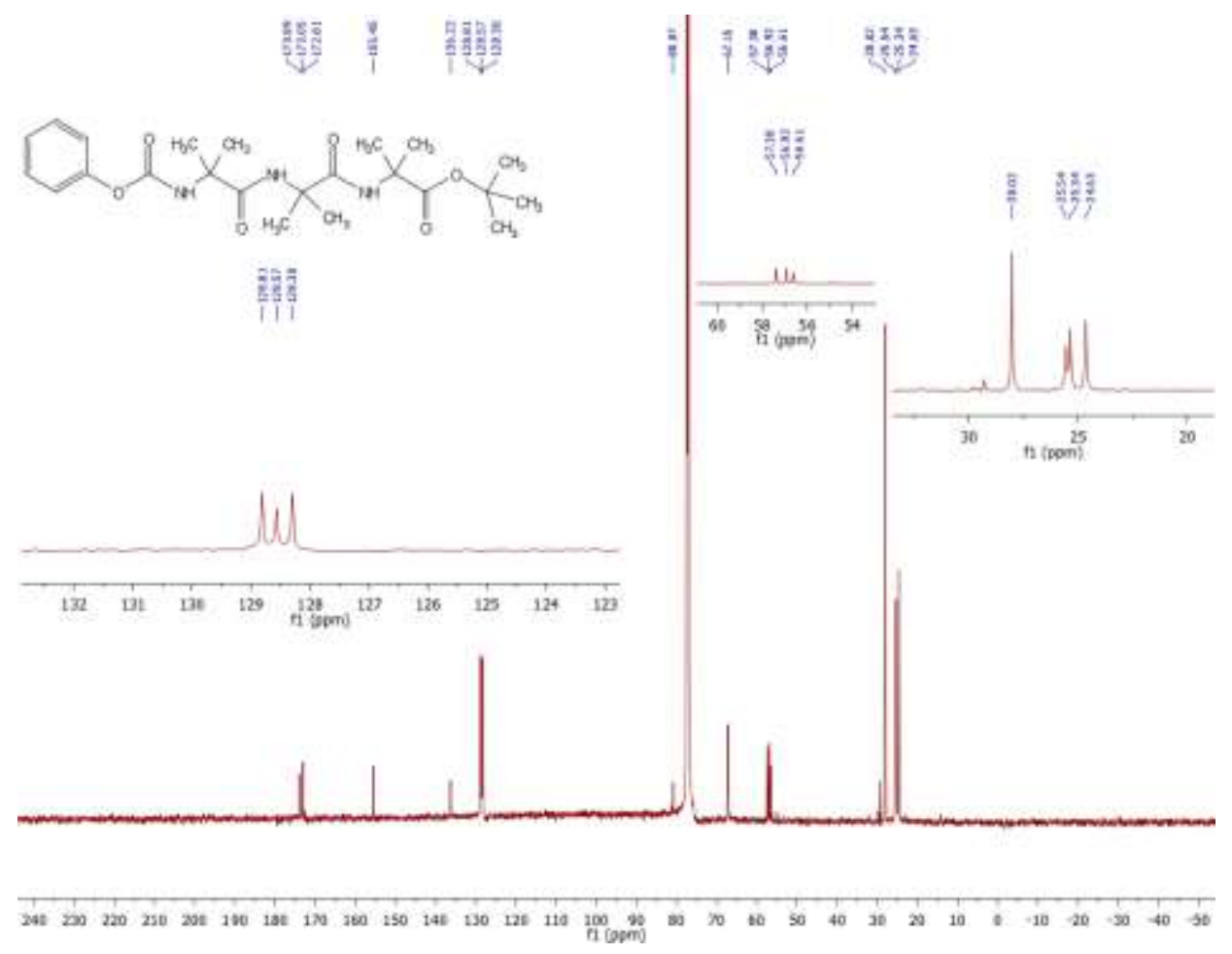

Fig. S11 ${ }^{13} \mathrm{C}$ NMR of Z-(Aib) ${ }_{3}-\mathrm{COOtBu}$ in $\mathrm{CDCl}_{3}$ 


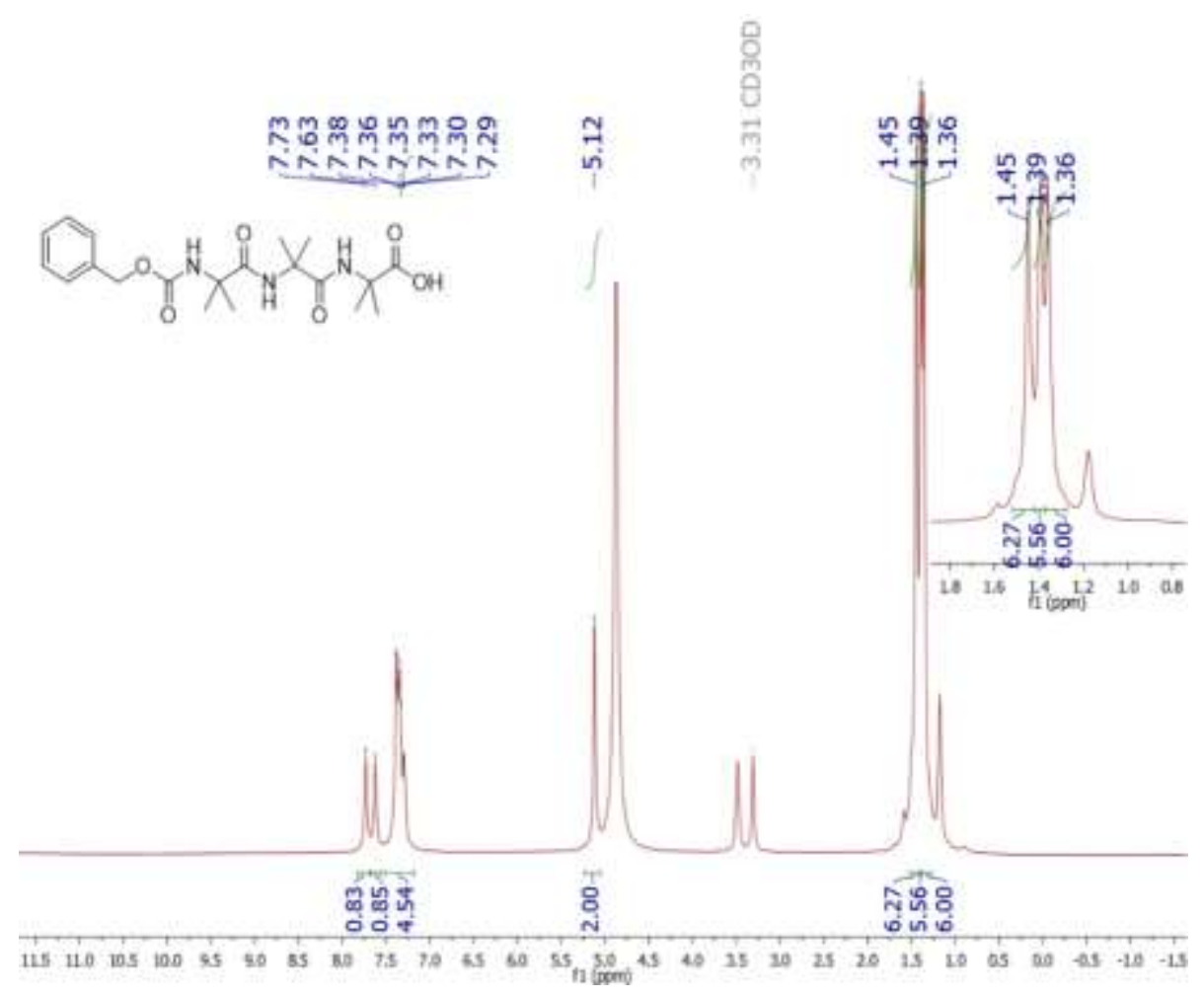

Fig. S12 ${ }^{1} \mathrm{H}$ NMR of Z-(Aib) ${ }_{3}-\mathrm{COOHin} \mathrm{CD}_{3} \mathrm{OD}$

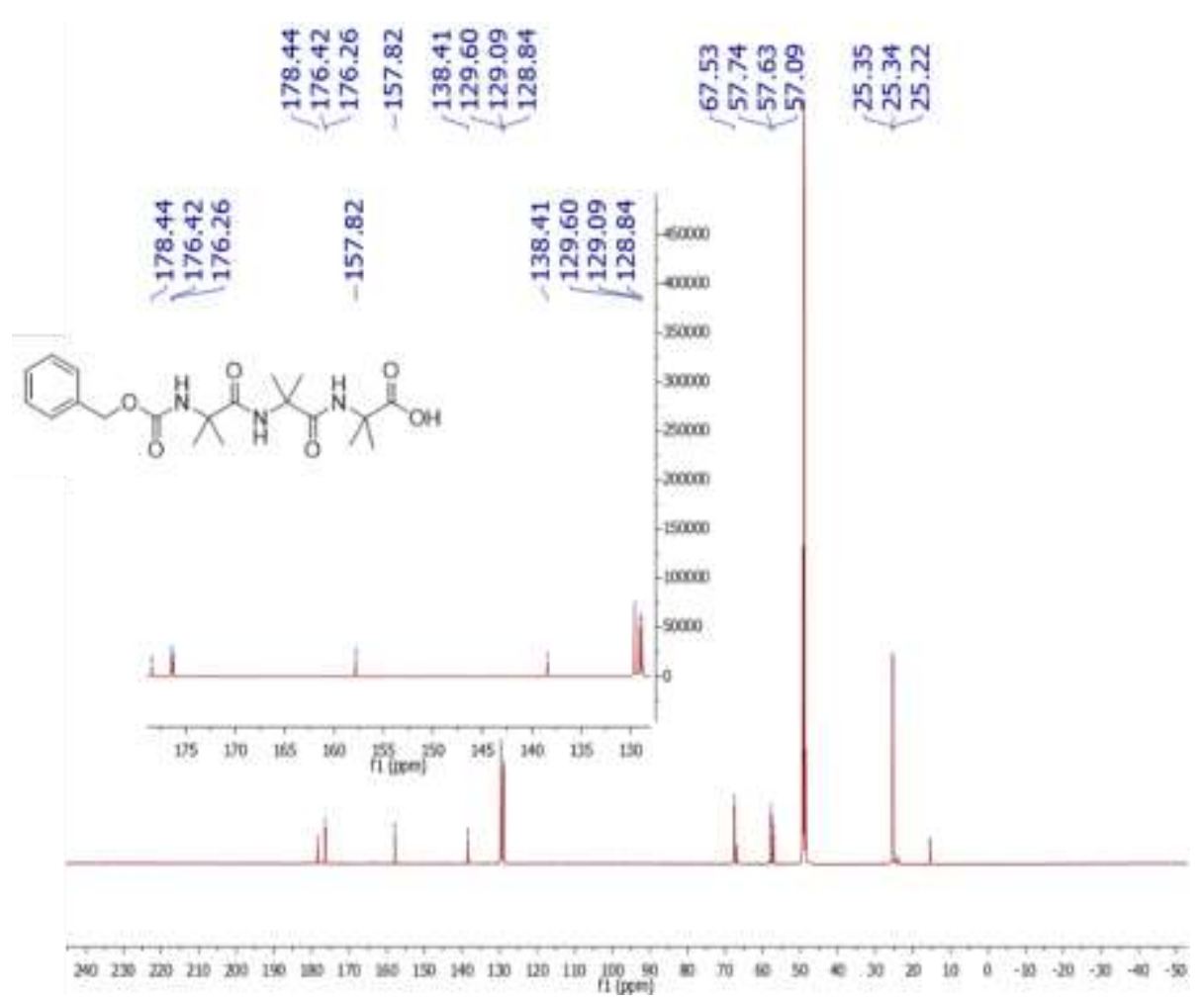

Fig. S13 ${ }^{13} \mathrm{C}$ NMR of $\mathrm{Z}-(\mathrm{Aib})_{3}-\mathrm{COOHin} \mathrm{CD}_{3} \mathrm{OD}$ 


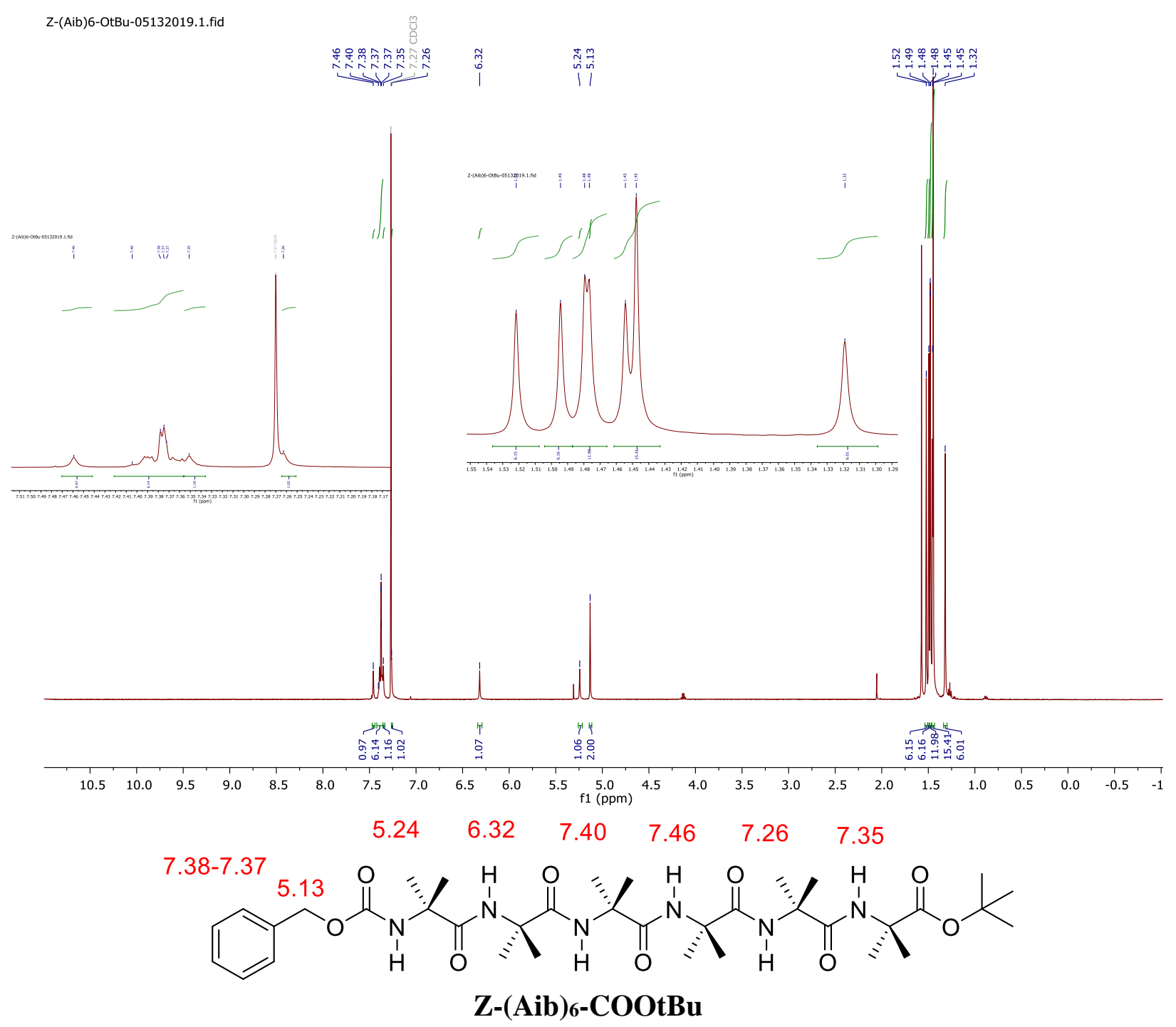

Fig. S14 ${ }^{1} \mathrm{H}$ NMR of Z-(Aib) ${ }_{6}-\mathrm{COOtBu}$ in $\mathrm{CDCl}_{3}$ and proposed assignments 


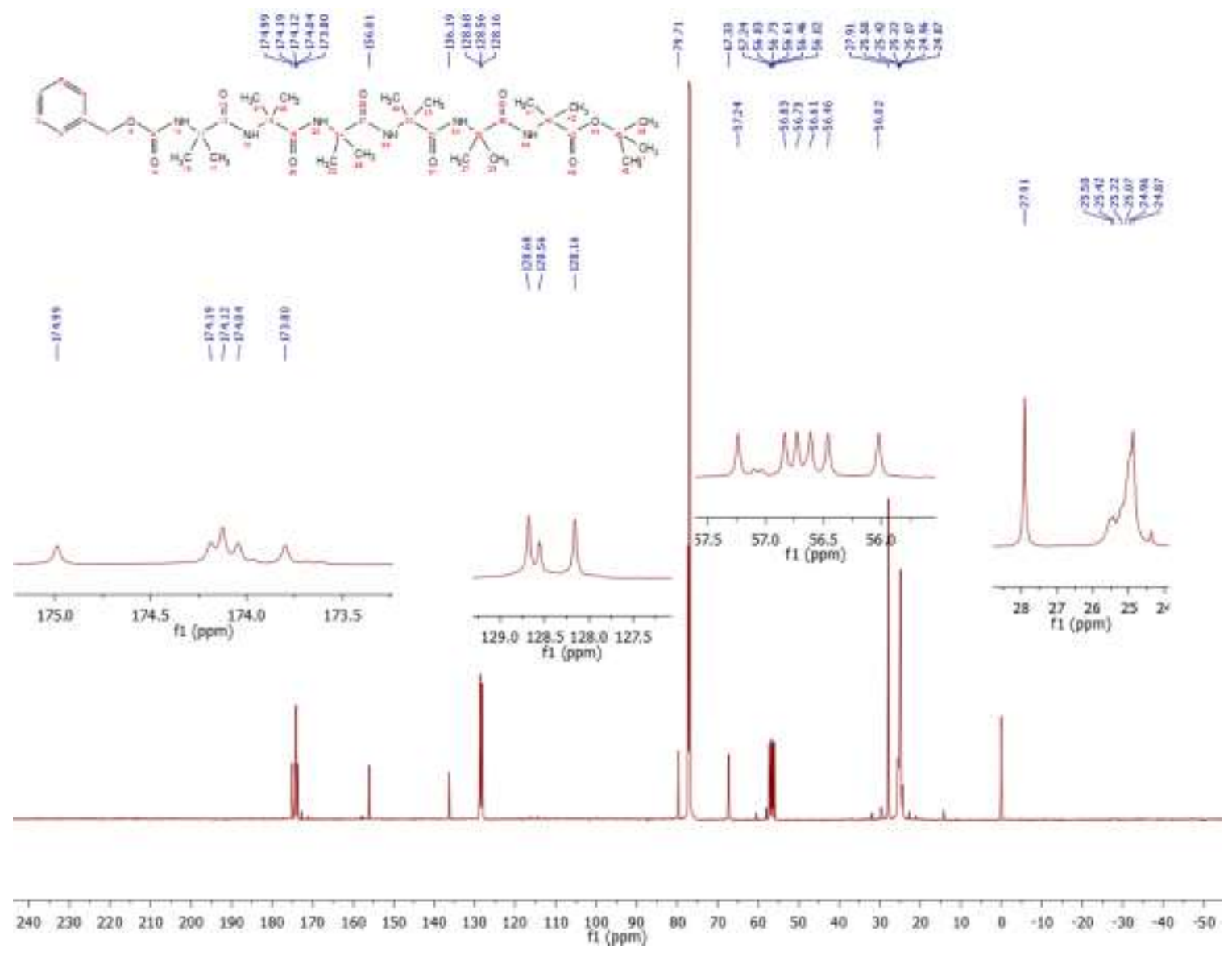

Fig. S15 ${ }^{13} \mathrm{C}$ NMR of Z-(Aib) ${ }_{6}-\mathrm{COOtBu}$ in $\mathrm{CDCl}_{3}$ 


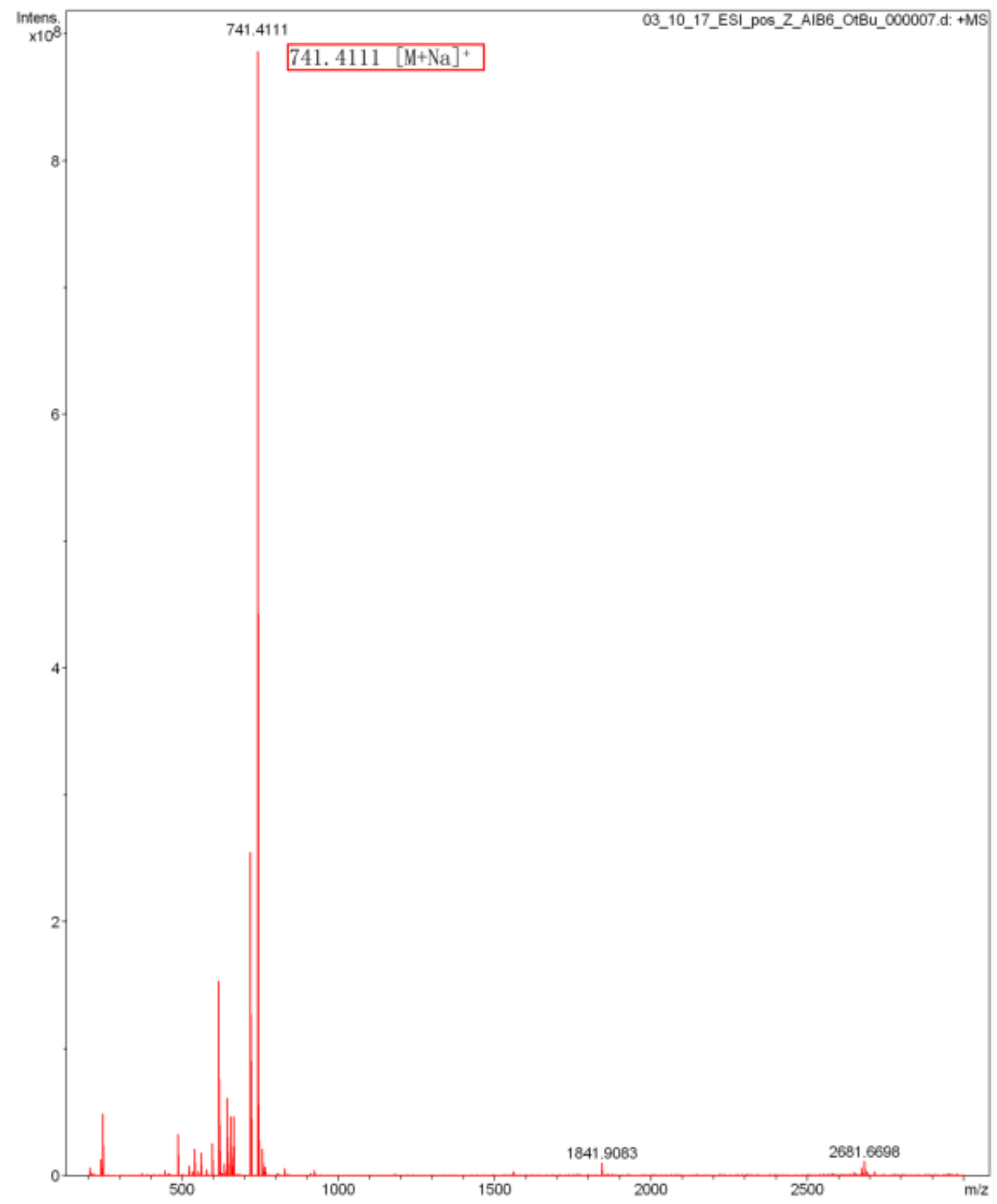

Fig. S16 ESI-MS spectra of 6 


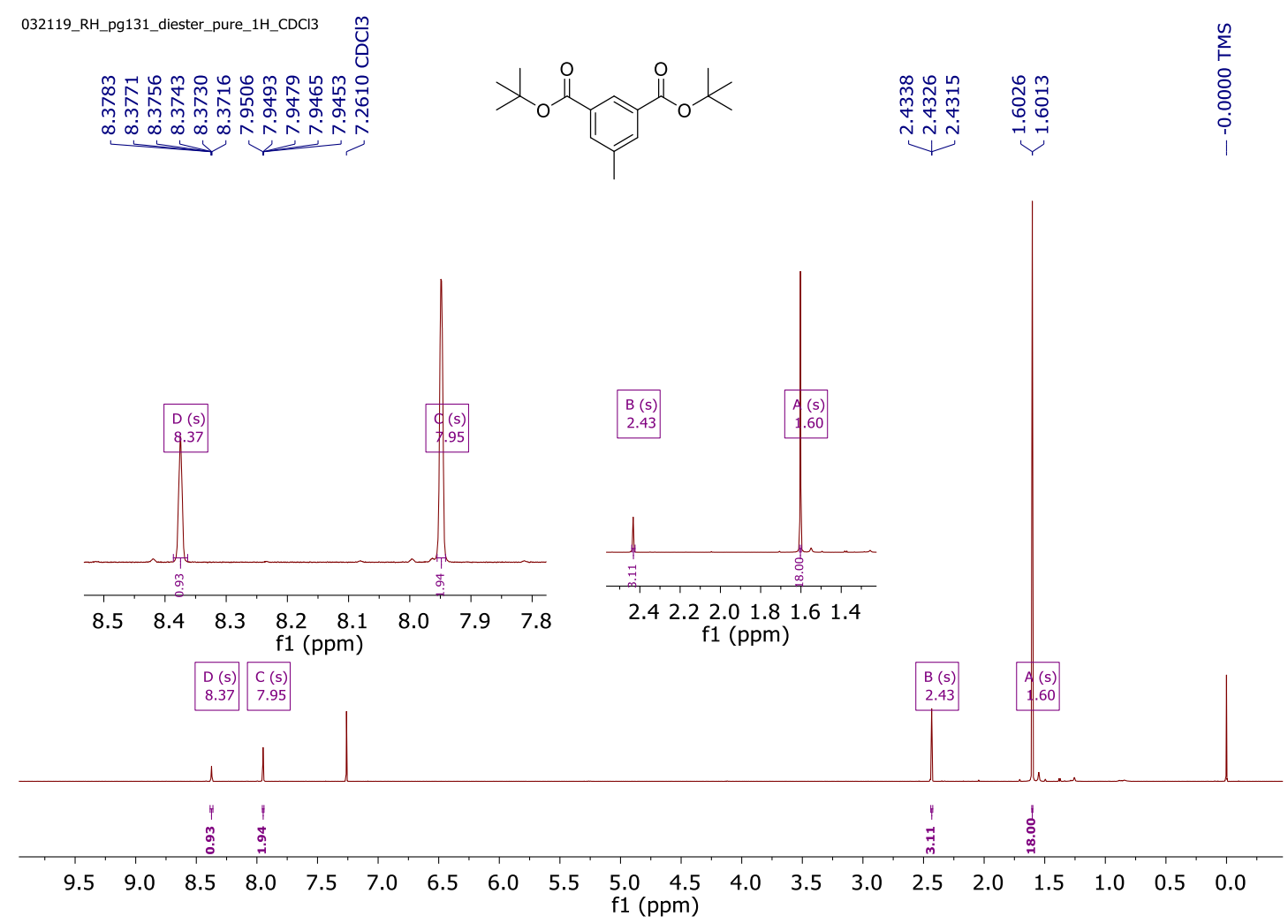

Figure S17. ${ }^{1} \mathrm{H}$ of di-tert-butyl 5-methylisophthalate in $\mathrm{CDCl}_{3}$

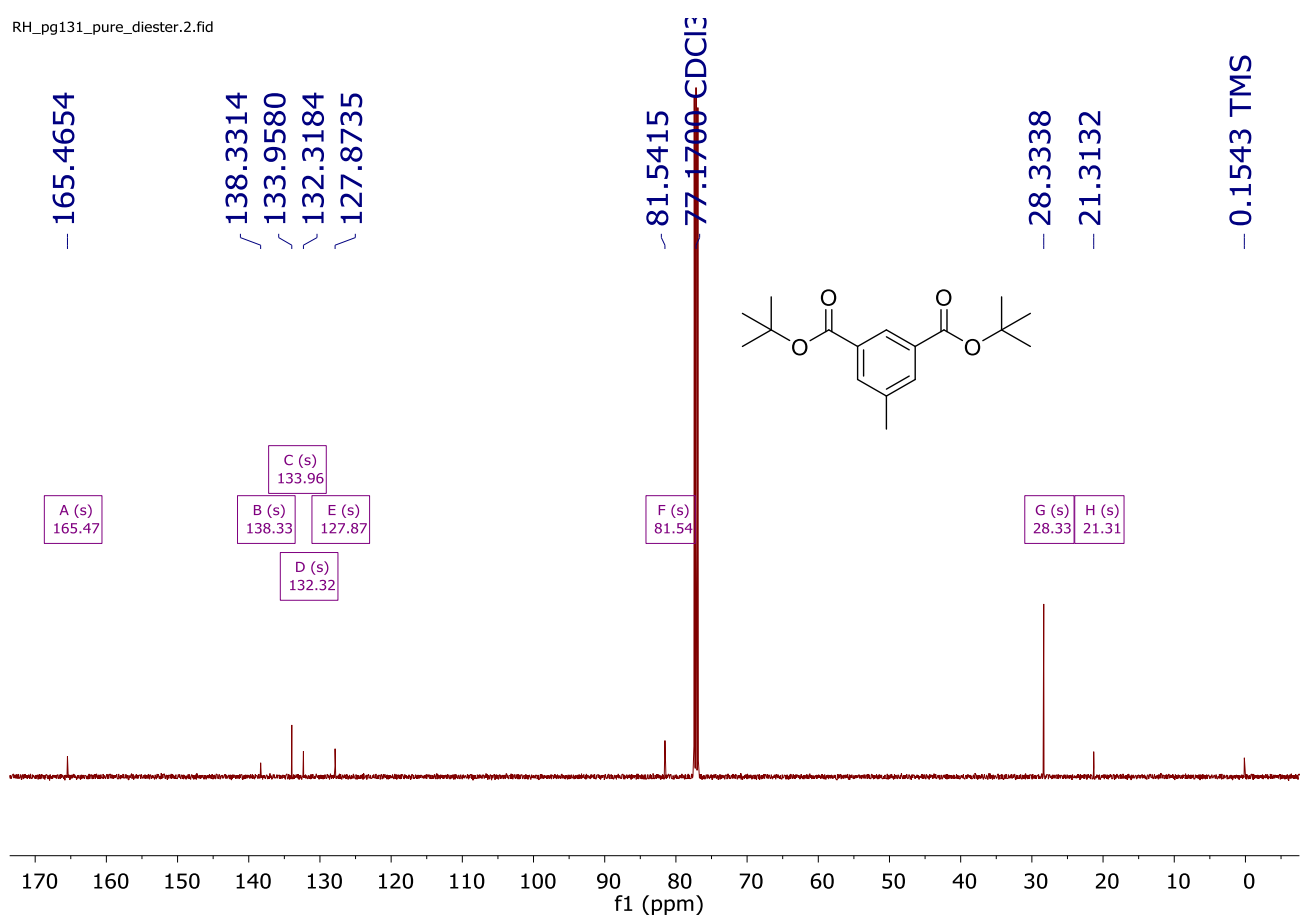

Figure S18. ${ }^{13} \mathrm{C}$ of di-tert-butyl 5-methylisophthalate (1) in $\mathrm{CDCl}_{3}$ 


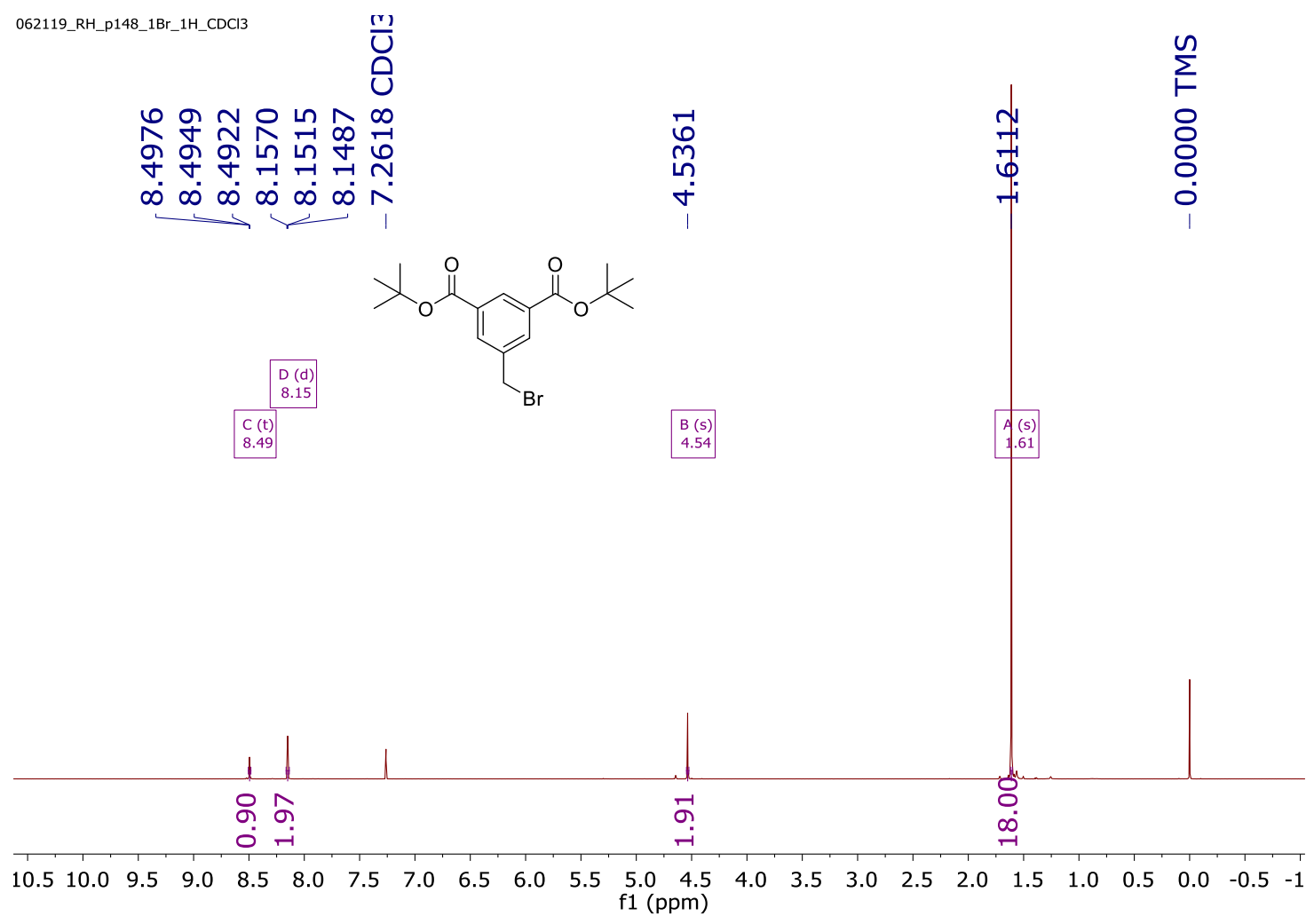

Figure S19. ${ }^{1} \mathrm{H}$ of di-tert-butyl 5-(bromomethyl)isophthalate (2a) in $\mathrm{CDCl}_{3}$

062119_RH_pg148_1Br_13C_CDCl3
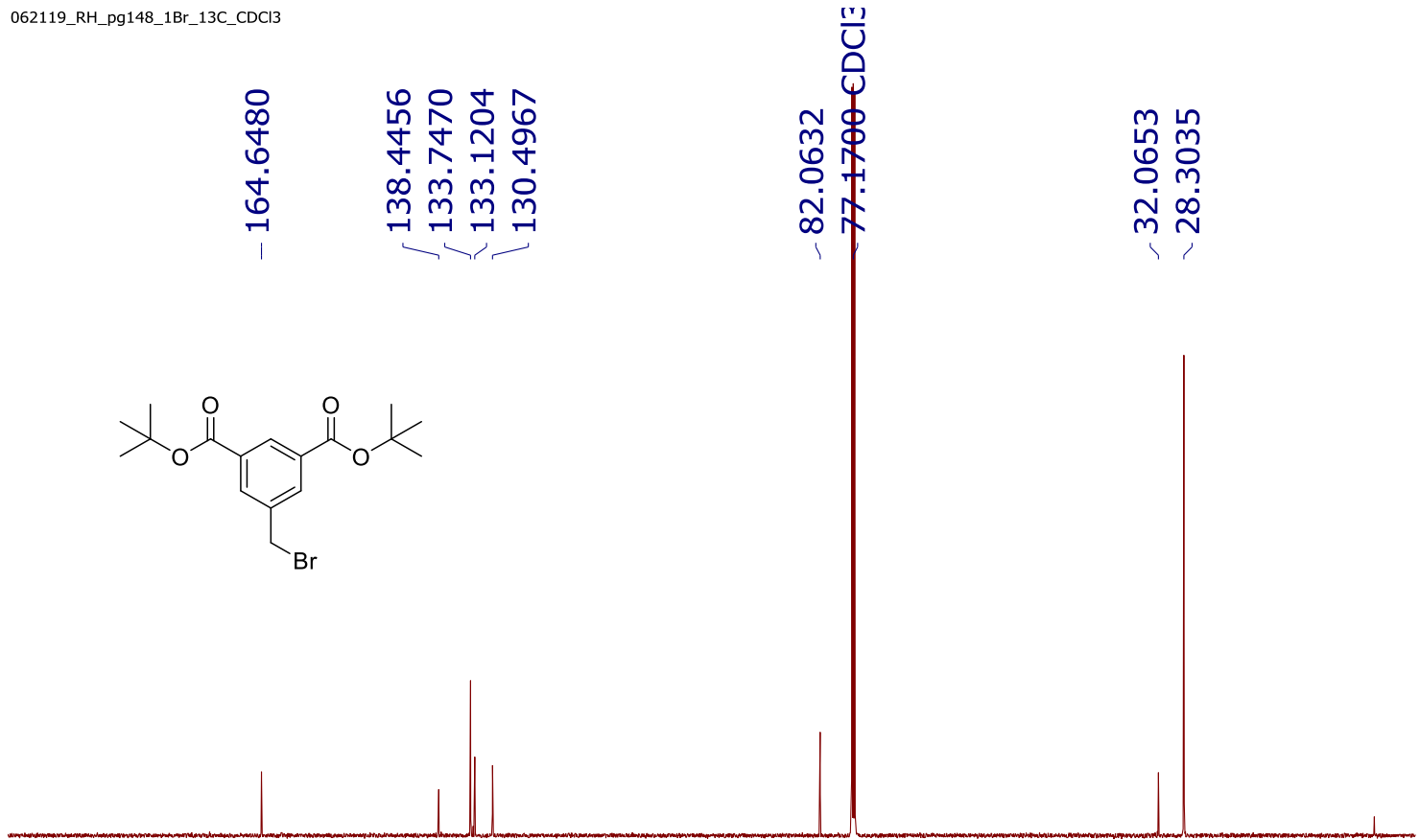

200

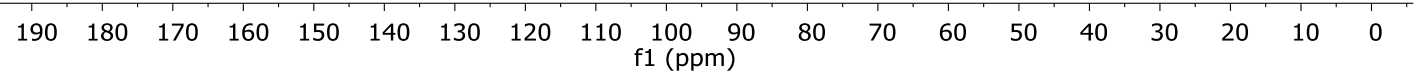

Figure S20. ${ }^{13} \mathrm{C}$ of di-tert-butyl 5-(bromomethyl)isophthalate (2a) in $\mathrm{CDCl}_{3}$ 


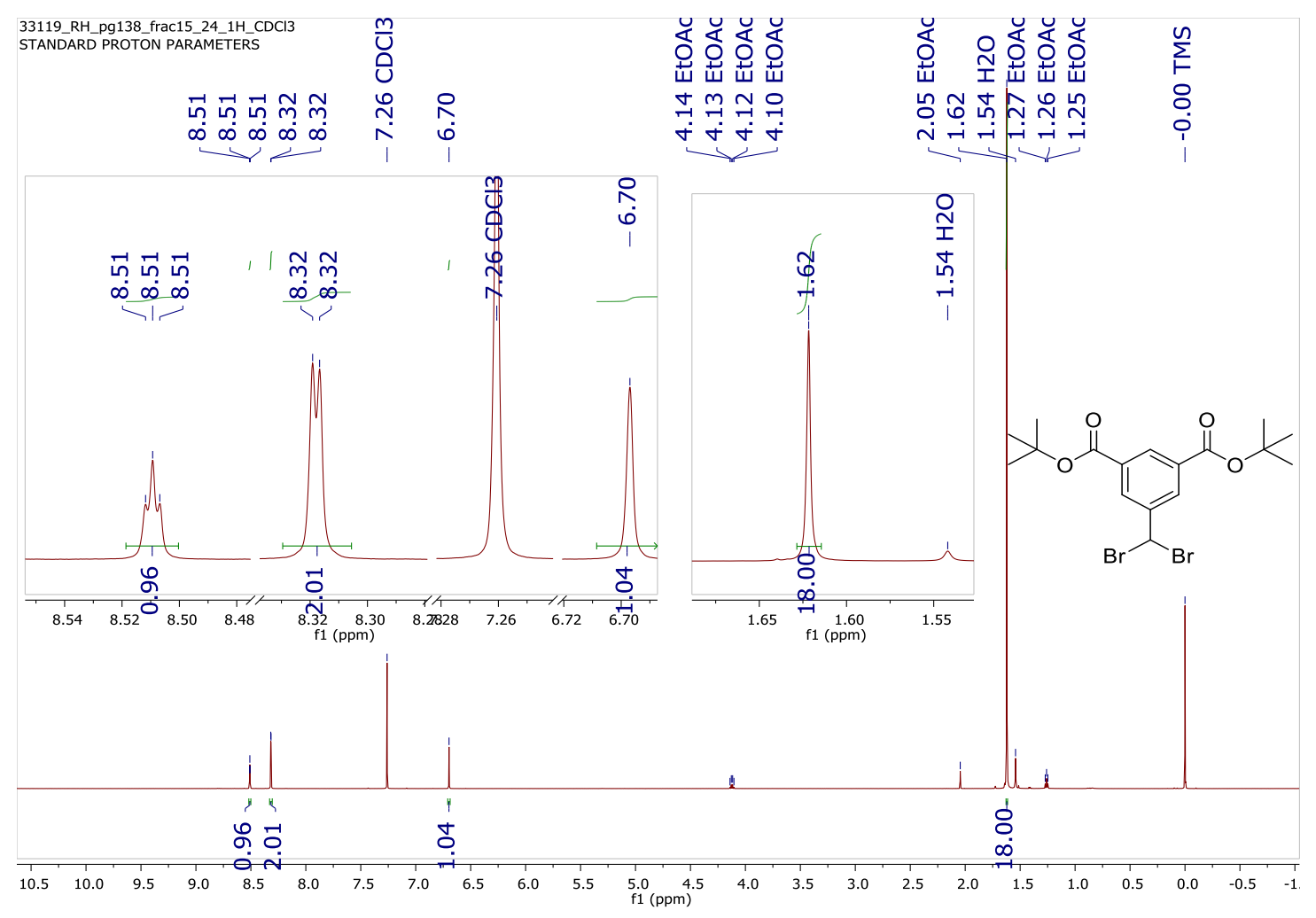

Figure S21. ${ }^{1} \mathrm{H}$ of di-tert-butyl 5-(dibromomethyl)isophthalate (2b) in $\mathrm{CDCl}_{3}$.

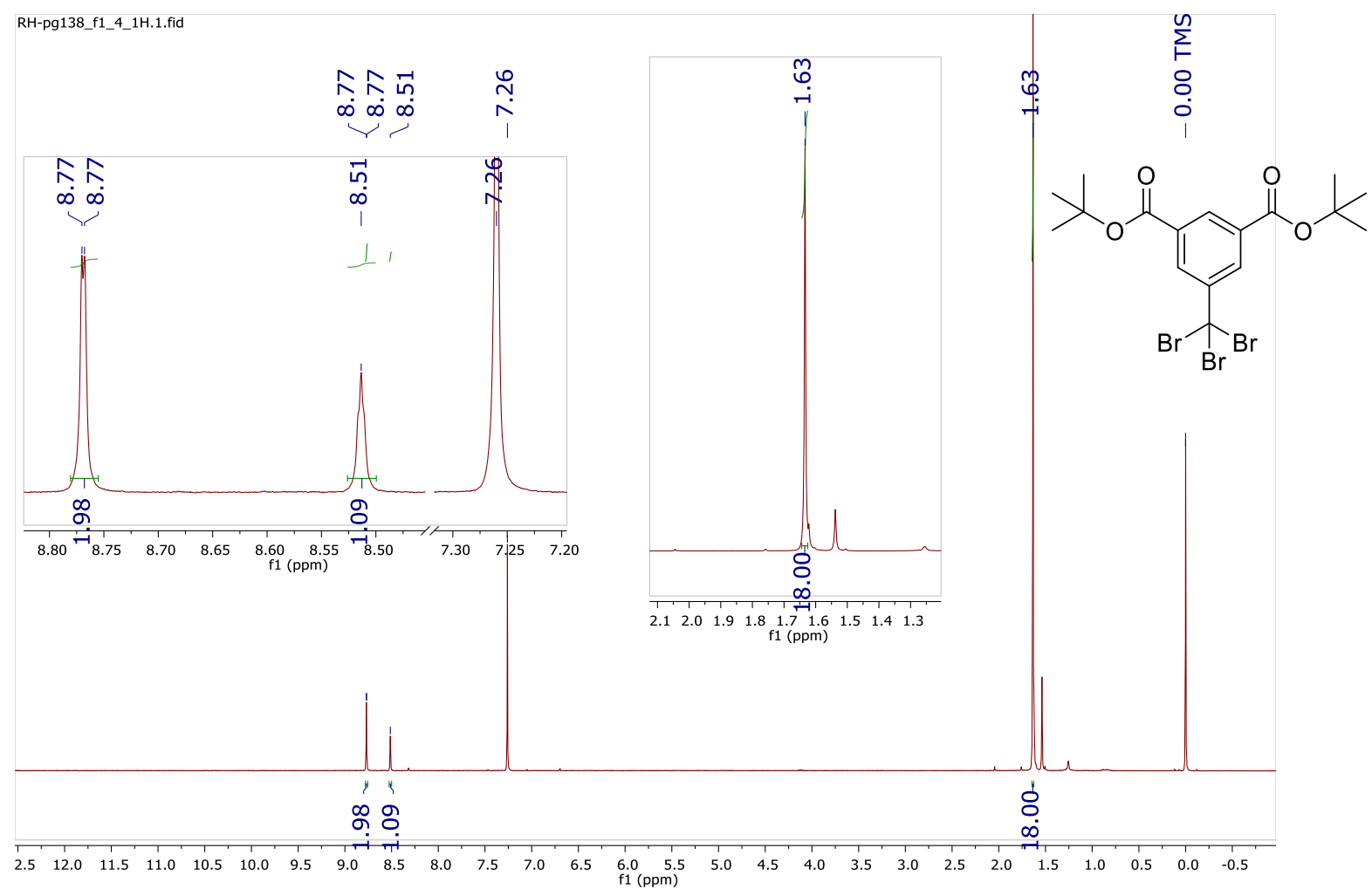

Figure S22. ${ }^{1} \mathrm{H}$ of di-tert-butyl 5-(dibromomethyl)isophthalate (2c) in $\mathrm{CDCl}_{3}$. 


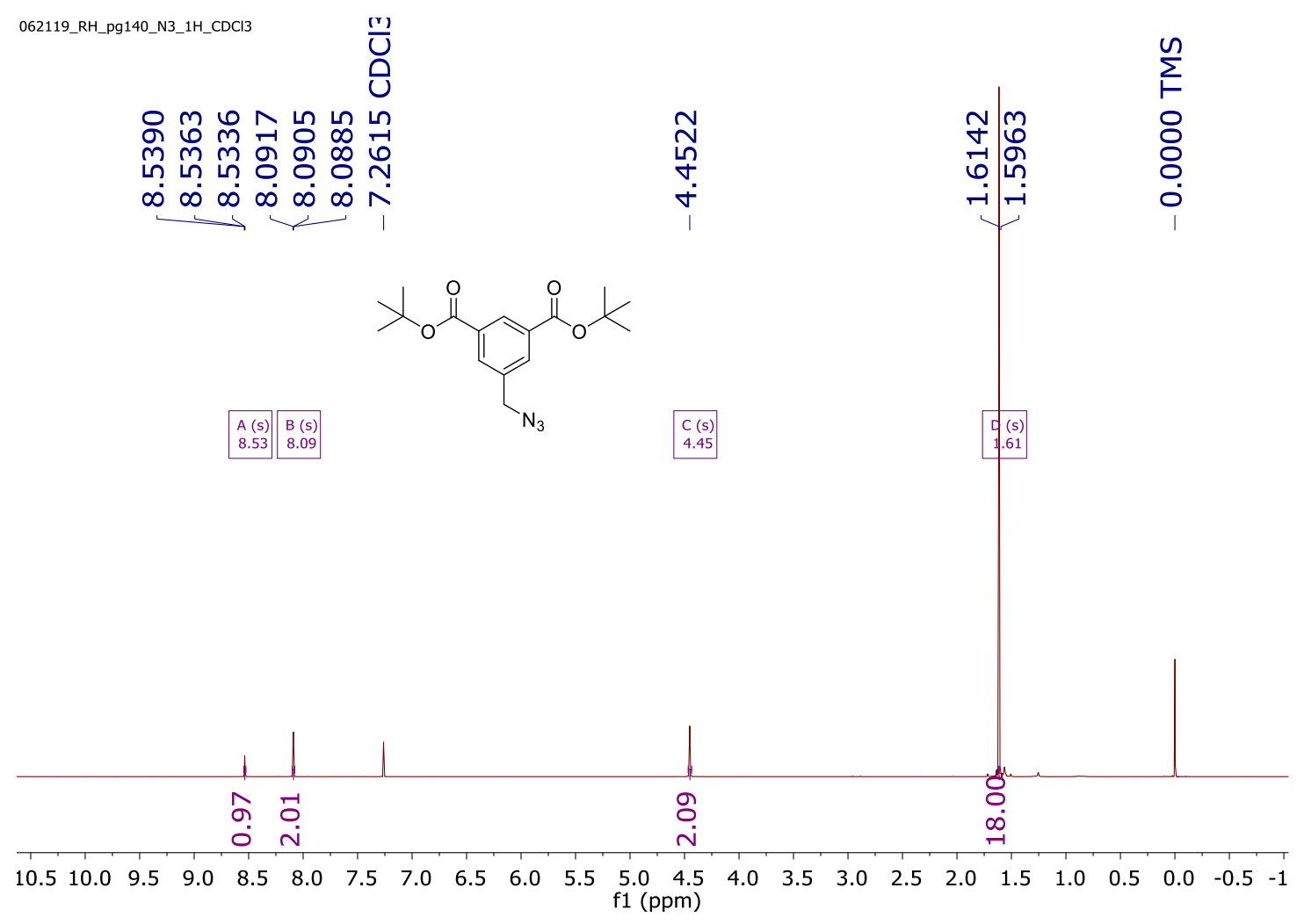

Figure S23. ${ }^{1} \mathrm{H}$ of di-tert-butyl 5-(azidomomethyl)isophthalate (3) in $\mathrm{CDCl}_{3}$.

062119_RH_pg140_N3_13C_CDCl3
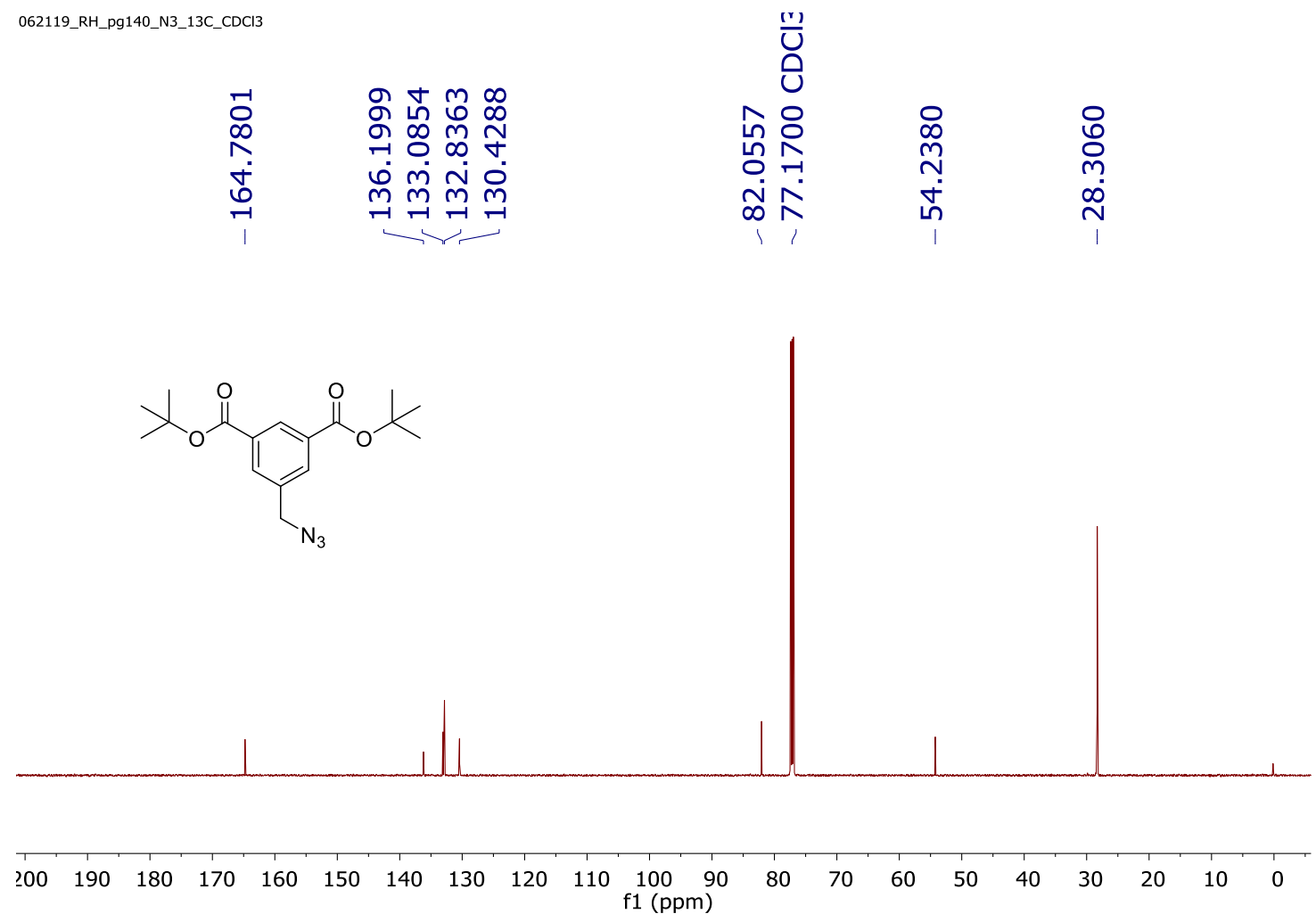

Figure S24. ${ }^{13} \mathrm{C}$ of di-tert-butyl 5-(azidomomethyl)isophthalate (3) in $\mathrm{CDCl}_{3}$. 


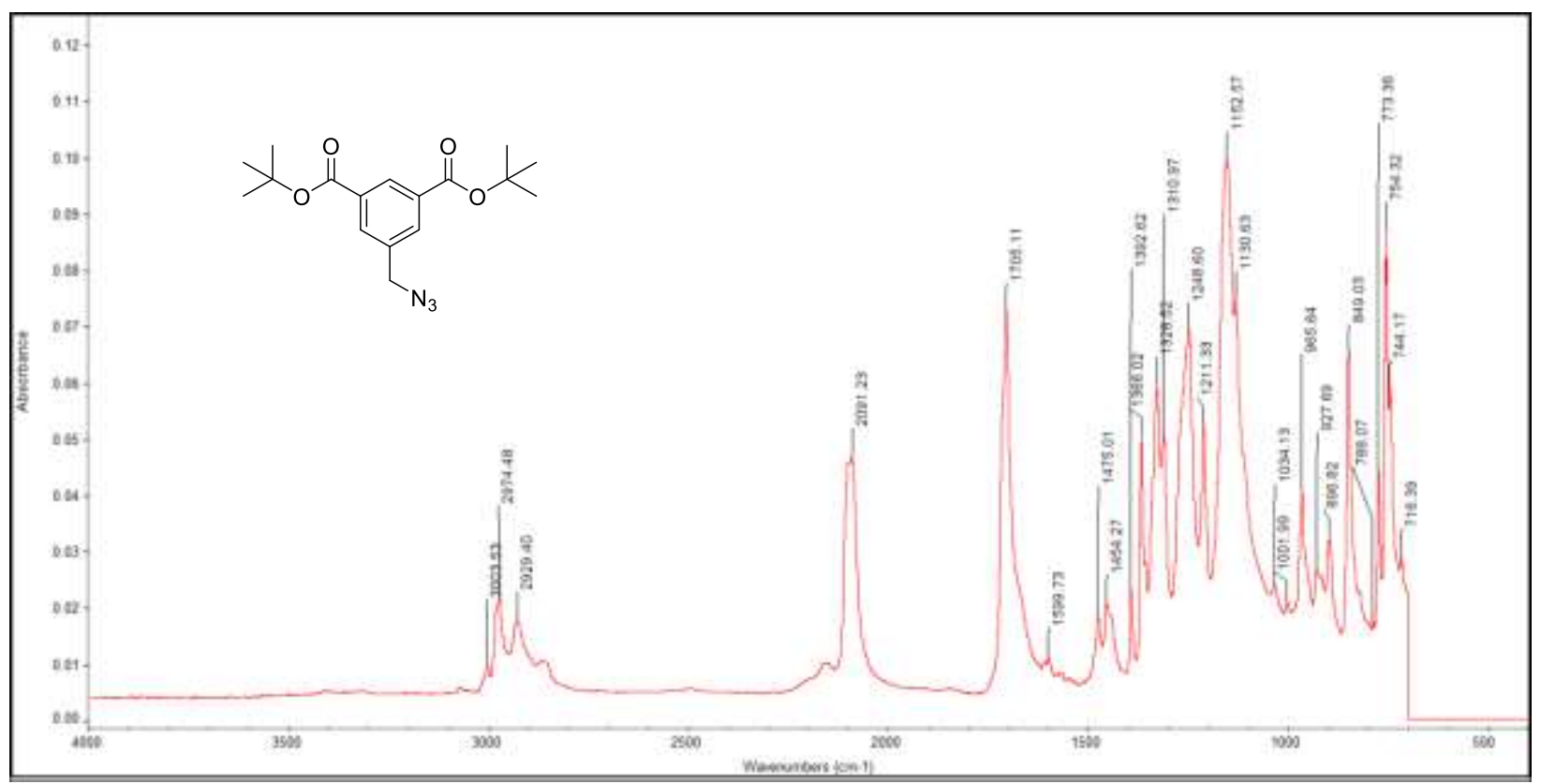

Figure S25. FTIR-ATR of di-tert-butyl 5-(azidomomethyl)isophthalate (3)

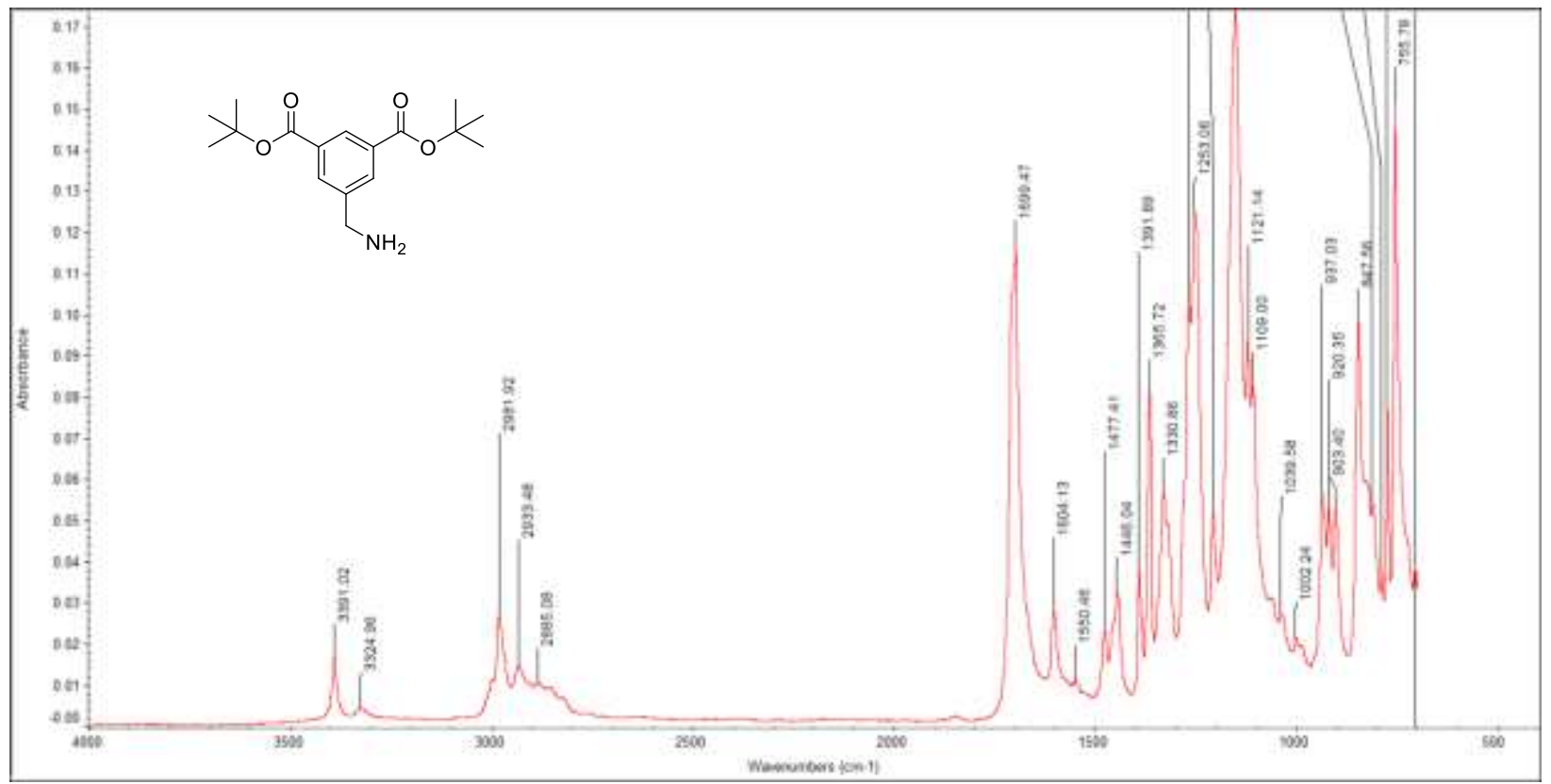

Figure S26. FTIR-ATR of di-tert-butyl 5-(aminomomethyl)isophthalate (4) 


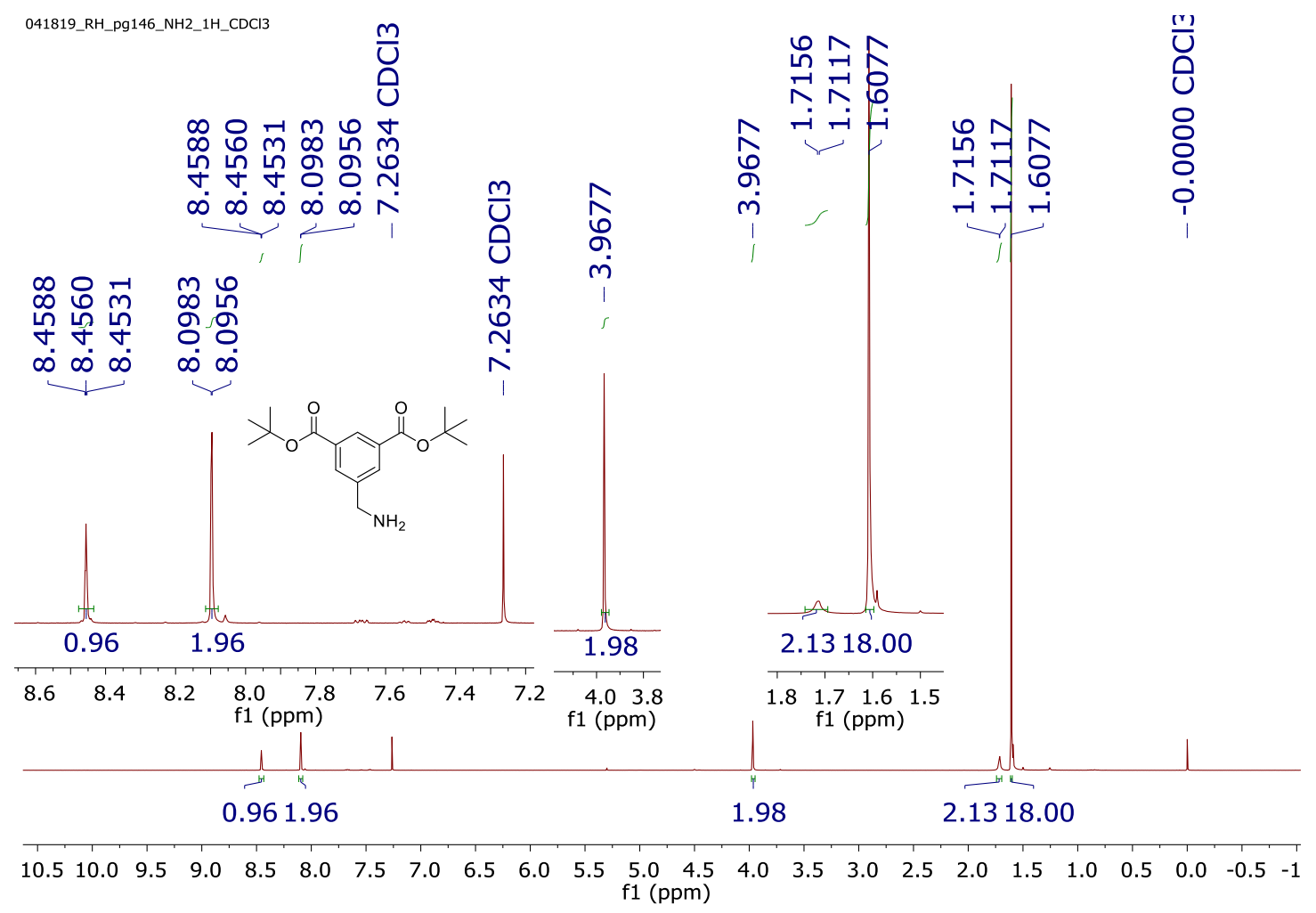

Figure S27. ${ }^{1} \mathrm{H}$ of di-tert-butyl 5-(aminomomethyl)isophthalate (4) in $\mathrm{CDCl}_{3}$.

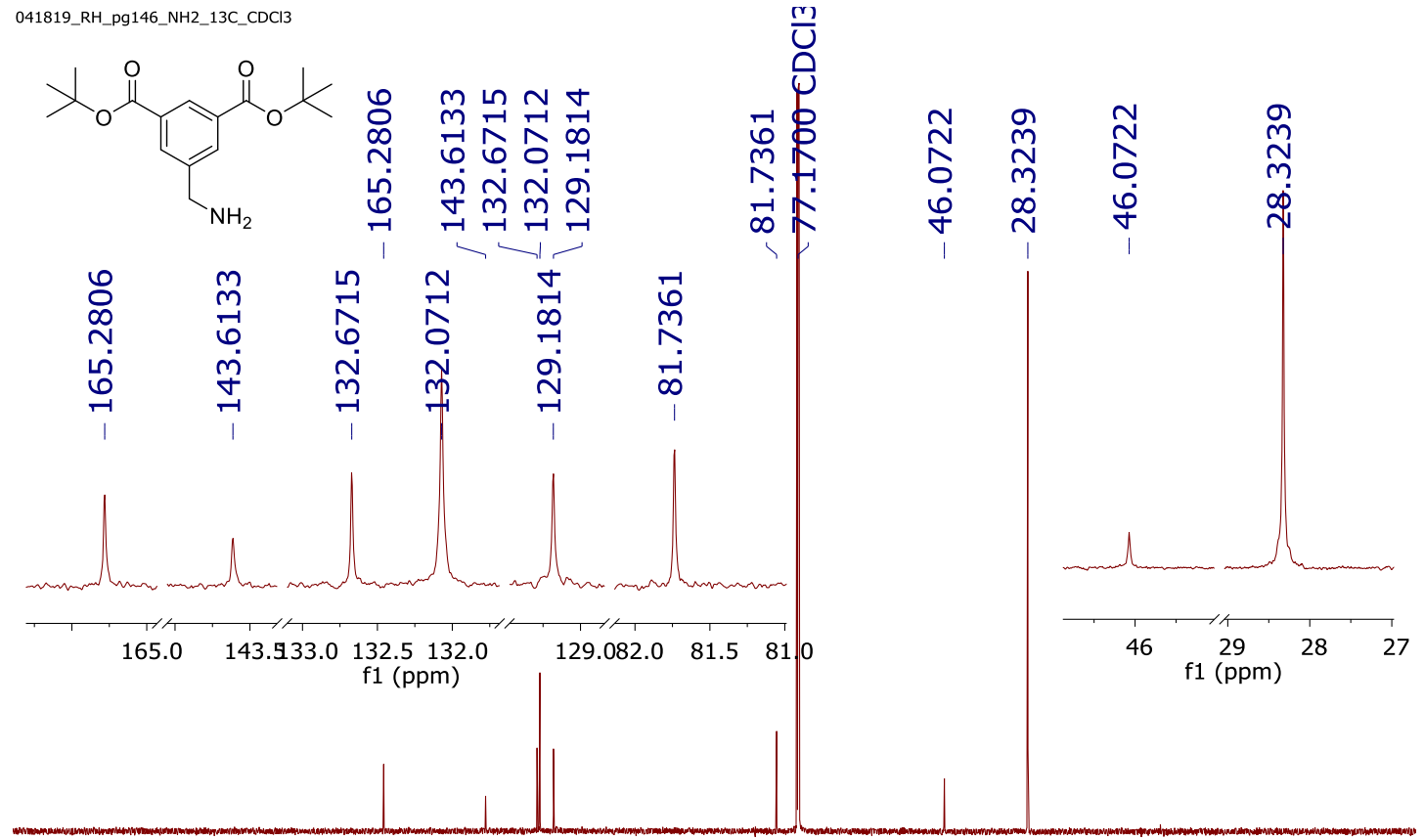

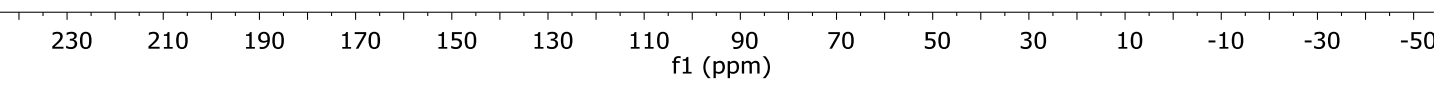

Figure S28. ${ }^{13} \mathrm{C}$ of di-tert-butyl 5-(aminomomethyl)isophthalate (4) in $\mathrm{CDCl}_{3}$. 


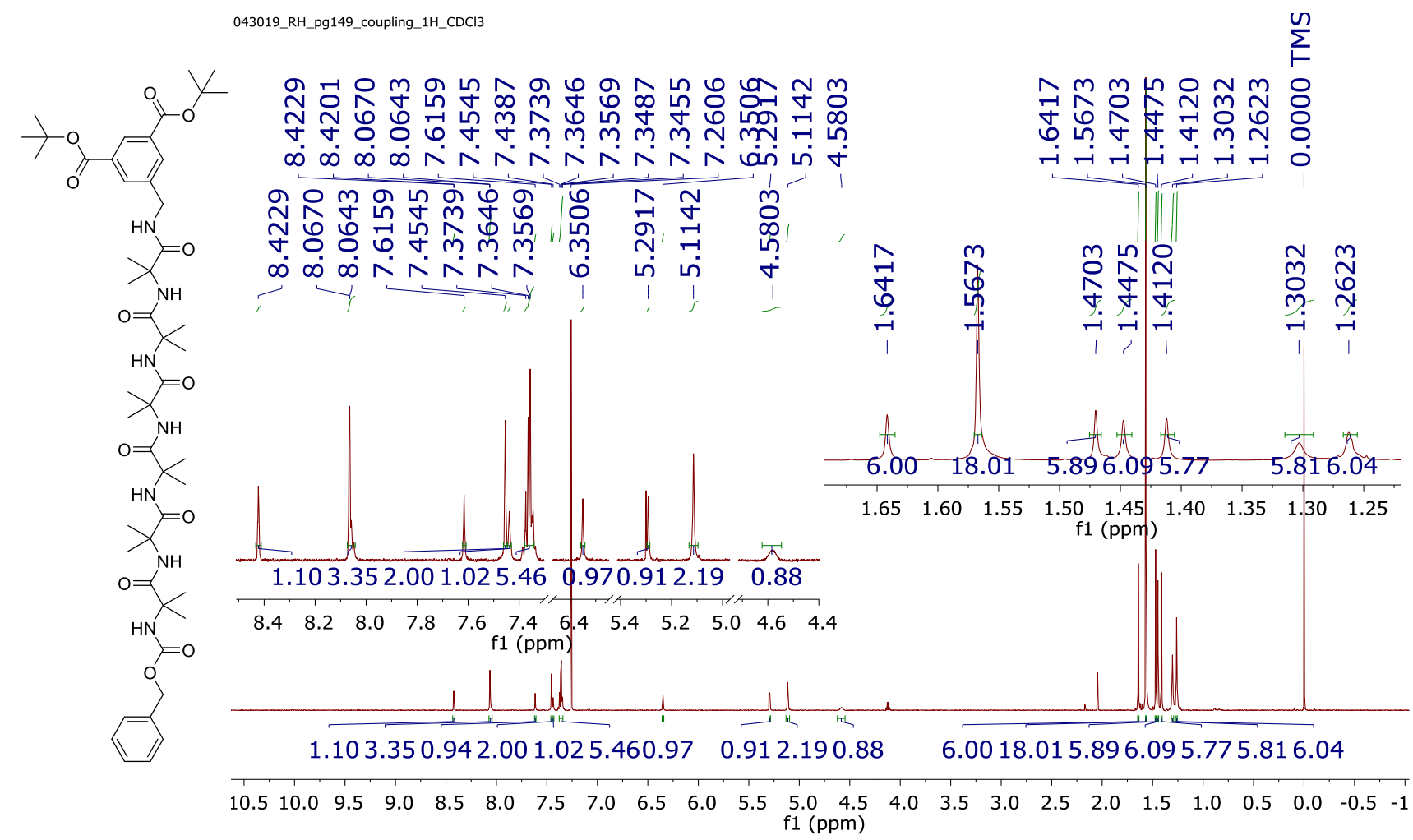

Figure S29. ${ }^{1} \mathrm{H}$ of $\mathrm{Z}$-(Aib) 6 -IpatBu (5) in $\mathrm{CDCl}_{3}$

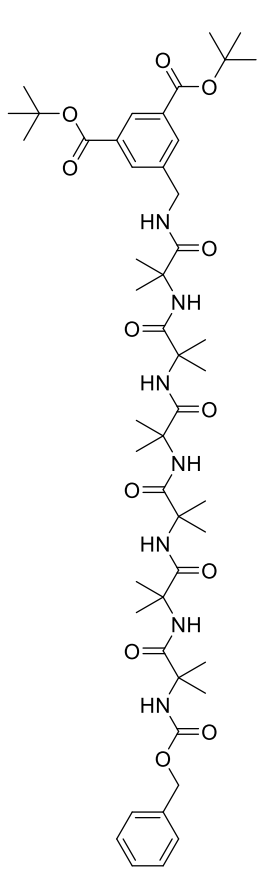

062719_RH_pg151_coupling_prot_13C_CDCl3

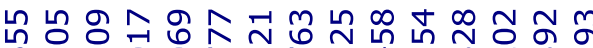
○내 ம்

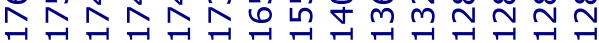
n

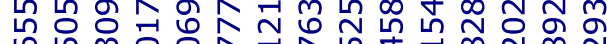

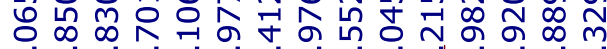

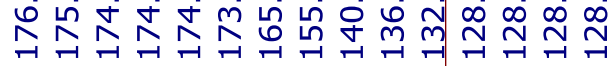
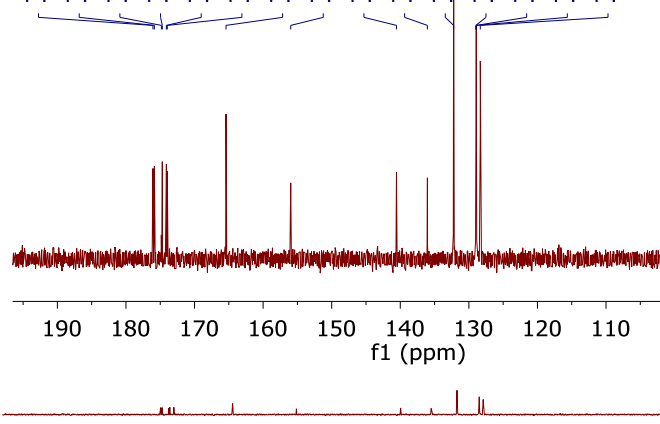

$\begin{array}{lllllllll}190 & 180 & 170 & 160 & 150 & 140 & 130 & 120 & 110\end{array}$

Figure S30. ${ }^{13} \mathrm{C}$ of $\mathrm{Z}$-(Aib) 6 -IpatBu (5) in $\mathrm{CDCl}_{3}$ 


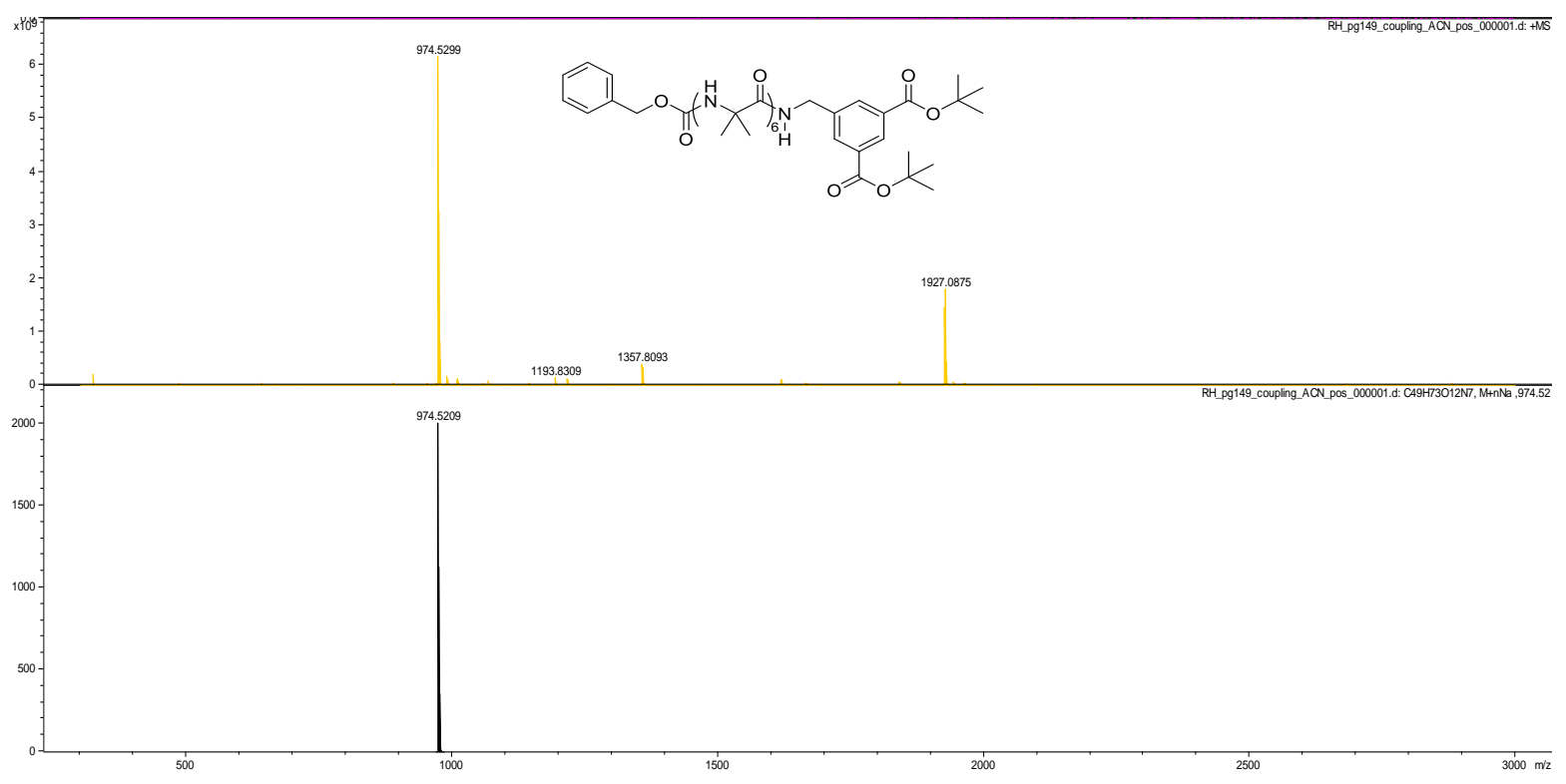

Figure S31. HRMS (ESI) of Z-(Aib)6-IpatBu (5) in $\mathrm{CDCl}_{3}$

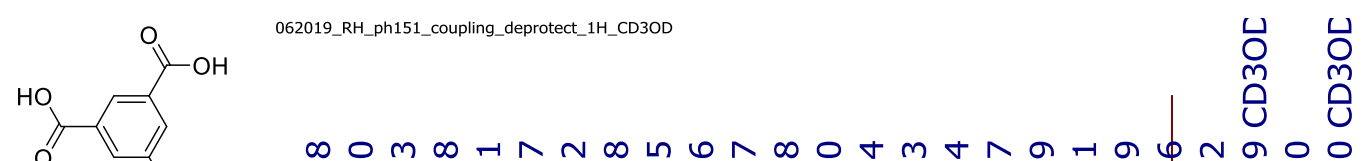

冓 นี

$\stackrel{\mathrm{HN}}{\mathrm{HN}}=\mathrm{O}$<smiles>CC(C)(N)C(N)=O</smiles>
$\infty \infty \infty \infty \infty \infty \wedge)$<smiles>CCNC(=O)C(C)(C)NC(=O)C(C)(C)NC(=O)C(C)(C)NC(=O)C(C)(C)NC(=O)C(C)(C)NC(=O)OCc1ccccc1</smiles>
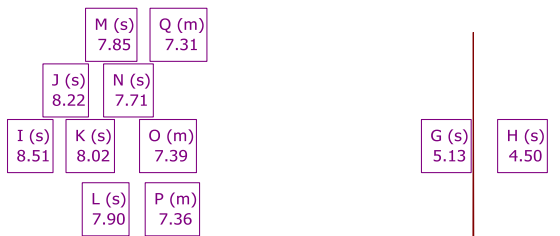

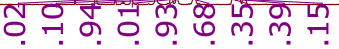
-inimiomini

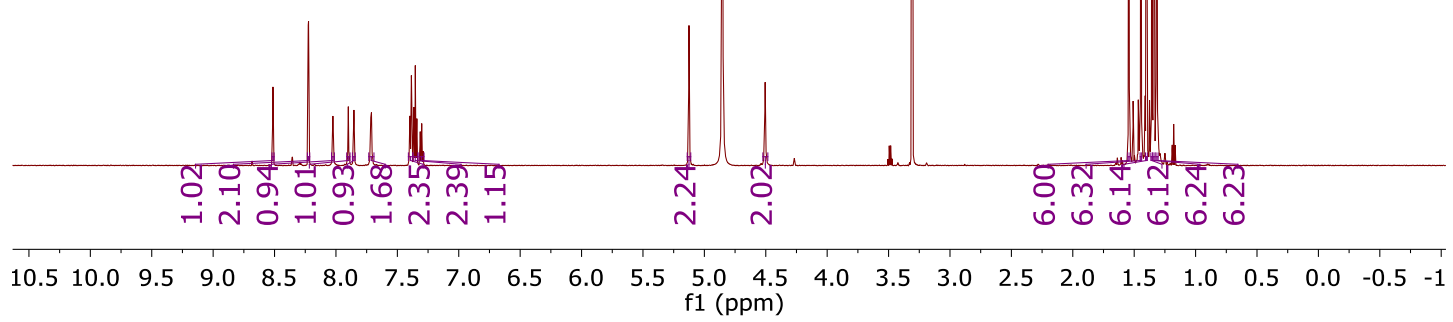

Figure S32. ${ }^{1} \mathrm{H}$ of $\mathrm{Z}$-(Aib) 6 -Ipa (6) in $\mathrm{CD}_{3} \mathrm{OD}$ 


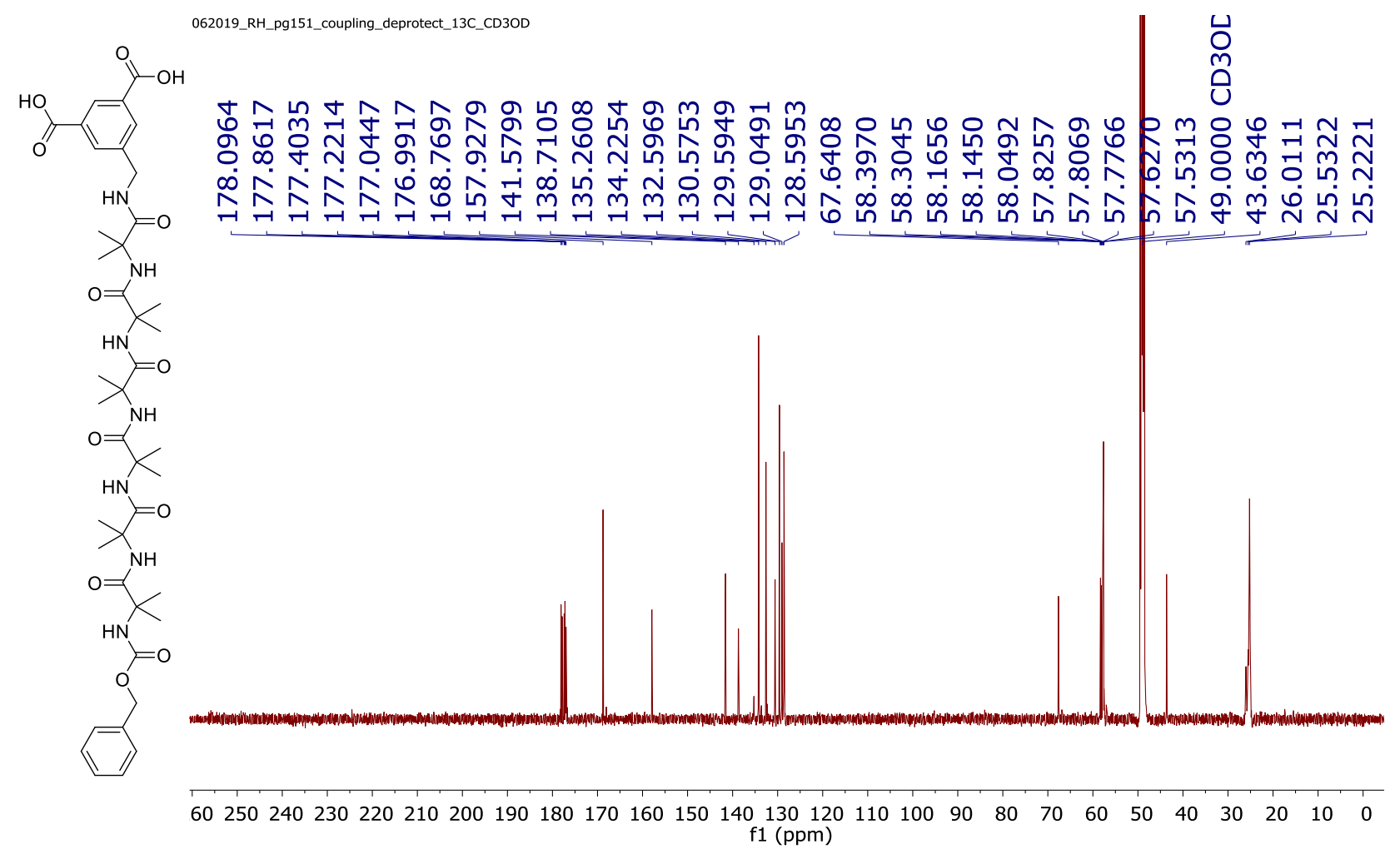

Figure S33. ${ }^{13} \mathrm{C}$ of $\mathrm{Z}$-(Aib) ${ }_{6}$-Ipa (6) in $\mathrm{CD}_{3} \mathrm{OD}$ 
Table S1. Crystal data and structure refinement for $\mathrm{Z}$-(Aib)6-COOtBu = hexamer_P21c_final.

Identification code

Empirical formula

Formula weight

Temperature

Wavelength

Crystal system

Space group

Unit cell dimensions

Volume

$\mathbf{Z}$

Density (calculated)

Absorption coefficient

F(000)

Crystal size

Theta range for data collection

Index ranges

Reflections collected

Independent reflections

Completeness to theta $=\mathbf{2 5 . 2 4 2 ^ { \circ }}$

Absorption correction

Max. and min. transmission

Refinement method

Data / restraints / parameters

Goodness-of-fit on $\mathbf{F}^{2}$

Final $\mathrm{R}$ indices [I $>2 \operatorname{sigma}(\mathrm{I})$ ]

$\mathbf{R}$ indices (all data)

Extinction coefficient

Largest diff. peak and hole
hexamer_P21c_final

C41.25 H69 N6 O11

825.02

120(2) K

$0.71073 \AA$

Monoclinic

$\mathbf{P 2} \mathbf{1}_{1} / \mathbf{c}$

$a=21.548(2) \AA \quad \alpha=90^{\circ}$.

$b=25.367(3) \AA$

$\beta=104.682(3)^{\circ}$.

$c=18.010(2) \AA$

9522.7(18) $\AA^{3}$

8

$1.151 \mathrm{Mg} / \mathrm{m}^{3}$

$0.083 \mathrm{~mm}^{-1}$

3572

$.55 \times .10 \times .05 \mathrm{~mm}^{3}$

1.605 to $25.349^{\circ}$.

$-25<=\mathrm{h}<=25,-29<=\mathrm{k}<=29,-21<=\mathrm{l}<=19$

57186

$17106[$ R(int $)=0.0745]$

$98.5 \%$

Semi-empirical from equivalents

0.7452 and 0.5719

Full-matrix least-squares on $\mathbf{F}^{2}$

17106 / 2108 / 1228

1.189

$\mathrm{R} 1=0.1116, \mathrm{wR} 2=0.2550$

$R 1=0.1681, w R 2=0.2842$

$\mathbf{n} / \mathbf{a}$

0.587 and -0.709 e. $\AA^{-3}$ 